Historic, archived document

Do not assume content reflects current scientific knowledge, policies, or practices. 



\section{UNITED STATES DEPARTMENT OF AGRICULTURE}

\section{BULLETIN No. 1049}

Contribution from the Bureau of Biological Survey

E. W. NELSON, Chief

Washington, D. C.

$\nabla$

March 14, 1922

\section{GAME AS A NATIONAL RESOURCE}

By

T. S. PALMER

Expert in Game Conservation

\section{CONTENTS}

Importance of Game . . . . . . 1

Prineipal Kinds of Game in the United States. . . . . . . 2

Value of Game to the Farmer . . . . . . . . . . . 9

Value of Game from the Standpoint of Fealth . . . . . . 10

Returns from License Fees . . . . . . . . . . . . 11

Estimates of the Value of Game by State Officlals . . . . . 12

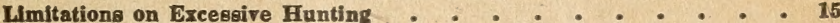

Records of Game Killed . . ? . . . . . . . 18

Enumerations of Game . . . . . . . . . . . . 23

Methods of Increasing Game Resources . . . . . . . . . 25

Coat of Maintaining Game . . . . . . . . . . 44

Buggestions for Making a Survey of Game . . . . . . . . 47

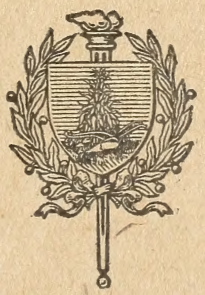

WABHINGTON

GOVRRNMIENT PRINTING OFFICE 



\section{UNITED STATES DEPARTMENT OF AGRICULTURE}

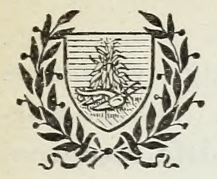

BULLETIN No. 1049

Contribution from the Bureau of Biological Survey,

E. W. NELSON, Chief.

Washington, D. C.

March 14, 1922

\section{GAME AS A NATIONAL RESOURCE.}

By T. S. Palmer, Expert in Game Conservation.

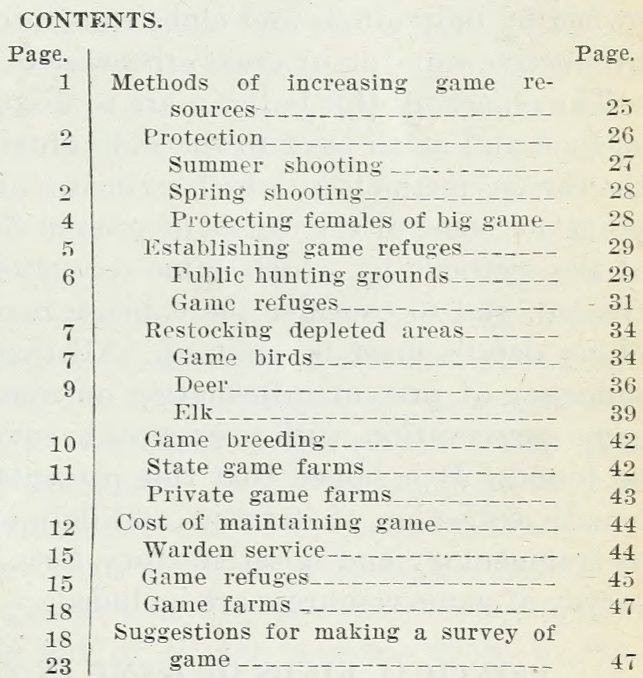

\section{IMPORTANCE OF GAME.}

Game is produced in every State in the Union, but its full importance as a national resource has not been generally recognized, and the best method of insuring its preservation and increase is a problem which as yet has been only partially solved. Under normal conditions in the United States probably more than 6,000,000 persons engage in hunting during the open season. The number increases

NoTE.-This bulletin summarizes present information on some of the larger problems of game conservation. It is for the information of individuals and associations interested in game preservation and is prepared with a view to the more general gathering of data for use in making a survey of game resources. 
from year to year and is now approximately 6 per cent of the total population, indicating that 1 person in every 16 hunts game of some kind.

With the information at present available only rough estimates of the value of game as a national resource are possible. By the estimating methods followed the annual value of the wild-life resources of the whole United States may be placed at several hundred million dollars.

The importance of game resources to any region is indicated by the extent to which they are advertised by transportation lines and by local interests in regions fortunate enough to possess game. 'The needs of sportsmen in the way of weapons, ammunition, special clothing, and other equipment form the foundation of business enterprises of considerable magnitude. The investment in shooting preserves owned by individuals and clubs runs into large figures and makes of productive value many areas otherwise of little or no use.

The objects of this bulletin are to discuss briefly the value of game as food and as an asset to the individual and to the State, to review the various methods by which estimates of such values are obtained, to point out some of the causes of present depleted conditions and some of the methods by which game resources may be preserved and increased, and to consider the expense involved in work of this kind. Many details must be omitted. All that is possible is to present a summary of present information on some of the larger questions of game conservation, with references to sources where further data may be found. It is hoped that this presentation may result in the systematic collection of statistics and data of a kind now available only in fragmentary and unsatisfactory form, and suggestions for such a survey of game resources are included.

\section{PRINCIPAL KINDS OF GAME IN THE UNITED STATES.}

The variety of North American game animals and birds hunted for sport, for recreation, or for food is large; but as some of the kinds are rare or local the number of species killed in any quantity for food is relatively small. Of these the most important are deer, rabbits, quail, and waterfowl.

\section{BIG GAME.}

DEER.

More than one-fourth of the States now have no deer hunting, either because the animals have been exterminated or because they have become so reduced in numbers that it has been necessary to close the season for several years to allow them to recuperate. (For 
list of. States, see p. 15; and map, fig. 1.) Statistics are available for only about one-third of the deer-hunting States, but include the more important hunting areas. Figures given for other States are necessarily estimates. The Biological Survey has published estimates for the years 1908, 1909, and 1910 of the number of deer killed in the States east of the Mississippi River, including Louisiana and Minnesota. The returns showed that in 15 States in 1908 the number was 59,878; in 1909, 57,494; and in 1910, in 17 States, 60,150. An estimate of the total number of deer killed throughout the United States in 1910 gave 75,000 to 80,000 , and a similar estimate of the deer killed in 1915 showed about 75,000. The latter total, covering 36 States (all in which deer hunting was permitted), included abnormally large numbers killed in California, Connecticut, and Vermont, which were offset somewhat by a decrease due to closing the seasons in Colorado and North Dakota. If the average dressed weight of a deer is taken as 150 pounds, the total weight of 75,000 deer is $11,250,000$ pounds. At 10 cents a pound this meat would be worth $\$ 1,125,000$, and at 20 cents a pound it would be worth $\$ 2,250,000$.

The region north of a line drawn along latitude $42^{\circ}$ and Mason and Dixon's line includes 19 States, 16 of which had deer hunting in 1920 (the exceptions being Connecticut, Rhode Island, and North Dakota). Of the 29 States south of this line, Delaware, Maryland. West Virginia, and 9 States in the corn belt had no deer hunting. and Missouri had very little. Omitting from consideration the States in which hunting is practically closed (leaving 16 States with open seasons in the northern tier and 17 in the southern tier), the possible deer crop is more than twice as great in the northern tier as in the southern, the States north of the line having under normal conditions a possible kill of 60,000 , whereas those to the south have less than 25,000. The only States to the south where the number is likely to exceed 5,000 are California and Texas, whereas at least 4 States to the North may exceed this limit, while in 4 of the New England States-Maine, New Hampshire, Vermont, and Massachusetts, where one deer, on the average, is obtained on each 5 square miles of territory - the kill might total 20,000, a number equal to the present possible crop of all the States to the south except Texas.

If the deer crop can be increased to 100,000 head a year, the quantity of meat would be increased to $15,000,000$ pounds, which at 20 cents a pound would be worth $\$ 3,000,000$. To attain this total it will be necessary to increase the present number of deer killed each year 25 per cent. No permanent increase can be expected during the next few years in the number killed in 6 of the principal StatesMaine, California, New York, Wisconsin, Minnesota, and Michigan. In fact, figures of the last few years are likely to show a decrease, 
for in Maine, New York, Michigan, Minnesota, and Wisconsin serious inroads have been made in the breeding stock because until recently laws have permitted the killing of does. In New York in 1919, when the season was open on both bucks and does, probably more than one-third of the total number of deer in the State were killed. On the other hand, some increase may be expected in the States in the Northwest and in the Rocky Mountains, and possibly in some of the Southern States, but whether the total will reach 100,000 a year will depend largely on the success attending the application of modern methods of conservation, such as complete protection of does and fawns, reasonable limits on the number a hunter may kill, and prevention of " jacking," "firelighting," "hounding," killing in the water, and market hunting.

\section{ELK.}

Elk formerly occurred and were hunted in nearly every State. Of the five forms generally recognized, the common elk (Cervus canadensis), once widely distributed east of the Mississippi, has retired to the fastness of the Rocky Mountains; the Roosevelt elk (Cervus roosevelti) is confined to the mountains of northwestern Washington; the Pacific coast elk (Cervus canadensis occidentalis) ${ }^{1}$ is found in limited numbers west of the Cascades and south of the Columbia River to northern California; the valley elk (Cervus nannodes) is restricted to one main herd in the upper San Joaquin Valley, Calif., and to a few small herds recently transferred to various parts of the State; and the Arizona elk (Cervus merriami) has been exterminated. At one point on its former range a flourishing herd of the Rocky Mountain elk has been established on the Sitgreares National Forest in Arizona. Estimates made a few years ago showed a total of approximately 72,000 elk in the United States, whereas to-day it is doubtful if the number is much in excess of 52,000 , of which about 25,000 are found in the Yellowstone National Park and adjoining regions.

Elk hunting has been closed in most States and is now restricted to a few counties in Idaho, Montana, and Wyoming, where the number is limited to one to each hunter.

The question of refuges is vital if elk are not to become extinct. The Yellowstone National Park forms the greatest natural refuge for these animals, but the herds, though they find abundant summer range within its boundaries, are obliged to leave the park in winter. The State of Washington has kept the season closed on elk for sereral years, and in the Olympic Mountains the Federal Govern-

${ }^{1}$ Some authorities consider Cervus roosevelti and Cervus canadensis occidentalis identical. 
ment has established a National Monument which includes the breeding grounds of the species and thus aids in its protection. In California the valley elk has been protected for years both by the State law and, on the present range near Bakersfield, by the owners of the Miller \& Lux ranch. From 1910 to 1920 nearly 4,000 elk were transferred from the Yellowstone Park and from Jackson Hole to a number of States in the West and in the East. Some of these herds, particularly those in Arizona, Colorado, and South Dakota, have thrived remarkably well, while others, located too near farms or cultivated lands, have done more or less injury to crops and have given rise to complaints and claims for damage.

No big game animal is easier to raise on a preserve or in semidomestication than elk when suitably located and provided with abundant food, and no game animal will increase more readily; but large herds can not be maintained in farming communities or near settlements, nor will mountain refuges preserve the species unless adequate winter range is provided. Notwithstanding the comparatively few and simple requirements of the animals, the adjustment of elk refuges to conditions in the West has given rise to some perplexing problems which have not thus far been satisfactorily solved.

MOOSE.

In Canada, moose and caribou are the principal meat producers among game animals. In the United States there is no caribou hunting except in Alaska, but moose are still hunted in Minnesota and Maine, there having been an open season for them in Maine except from 1915 to 1918 . It is worth while, therefore, to examine the conditions surrounding moose hunting somewhat in detail.

The center of moose hunting in eastern North America is probably in the State of Maine and in the Provinces of New Brunswick and Nova Scotia. In Maine, moose are confined to the northern and eastern sections, and probably not more than half the State can properly be considered moose country. In New Brunswick they are found in all the counties, and in Nova Scotia are hunted in all sections except on Cape Breton Island, where they have been protected for a number of years. This gives an area of about 16,500 square miles of moose territory in Maine, 28,000 in New Brunswick, and 18,300 in Nova Scotia, or a total of 62,800 square miles, a little less than the area of New England. In this region nearly 3,000 moose were recorded as killed in 1914, and probably at least 3,500 were actually killed that season. As each hunter is limited to a single moose, this indicates that more than 3,000 persons hunted moose, and on the a rerage one moose was obtained on every 20 square miles. 
Moose hunting on such a scale has been made possible by protection. Calves are protected throughout the area, and cows likewise have been protected, except in Nova Scotia prior to 1909. With this exception the limit has been one bull a year. The hunting season has varied in length from 3 months down to 10 days, and in 1920 it was open 10 days in Maine, $2 \frac{1}{2}$ months in New Brunswick, and $1 \frac{1}{2}$ months in Nova Scotia. ${ }^{2}$ In 1907 Nova Scotia required that every moose killed should be reported, and about 1908 New Brunswick adopted the same requirement, so it is now possible to ascertain approximately the number killed in each Province.

\section{SMALL GAME.}

RABBITS.

Rabbits probably constitute the largest, cheapest, and most generally available supply of game in the United States. Abundant almost everywhere, shot for sport and market, and free from nonsale restrictions in many States, they form an important item of food supply. The jack rabbits of the West, which are a serious pest in some States, are destroyed in enormous numbers-sometimes as many as 10,000 in a single drive-but only a relatively small number are placed on the market and find their way to eastern States. Cottontails, however, are found in every State in the Union and during the autumn and winter are hunted almost everywhere. In 23 States, comprising all those east of the Mississippi River and north of latitude $36^{\circ}$, and in addition California, Louisiana, Minnesota, and South Carolina, there are close seasons and other regulations, but in the other States there is, at present, no restriction on hunting (see map, fig. 3, p. 17.)

The Conservation Commission of New York estimated that about 465,000 cottontails were killed in 1918 in New York; the Game Commission of Pennsylvania estimated that in the open season of 1919 about 2,700,000 rabbits were killed in that State; and a game survey of Virginia for 1920 shows 293,625 killed in that State. Statistics or even estimates of the numbers killed or sold in most other States are not available. Perhaps it is not too much to assume that the total number of rabbits killed annually in the United States is not less than four for each hunter, or a total of about 25,000,000. Ordinarily rabbits are sold at from 10 to 30 cents apiece, but in the autumn of 1920 they retailed for as much as 50 or even 75 cents each. At an average of only 20 cents each the value of this supply of meat would be not less than $\$ 5,000,000$ annually, but more im-

2 Maine, 1905-1913, 6 weeks ; 1913-14, 1 month ; 1915-1918, closed ; 1919-20, 10 days. New Brunswick, 1905-1920, 21 months. Nova Scotia, 1905-6, 3 months; 1907-1914, 2 months; $1915-1918,2 \frac{1}{2}$ months; 1919 , 2 months; $1920,1 \frac{1}{2}$ months. 
portant than its ralue is the fact that a nutritious and relatively cheap meat is thus distributed and made arailable to a considerabl: number of persons who can ill afford to pay high prices for beef, mutton, and pork.

\section{GAME BIRDS.}

QTIII.

Every State has some species of quail. either natire or introduced. Probably no game except ducks is more generally hunted, particularly the eastern species commonly known as bob-rhite. Quail protection has passed through several stages. Formerly abundant in most States, the birds were first hunted for food by pioneers and early settlers: later, commercialized. they nere hunted and trapped for market in such enormous numbers that now they have become so reduced that their sale is prohibited almost everywhere. Even the rivilege of hunting them for sport has been withdrawn in a number. of States. In 1920 there was no quail shooting in 15 States-Colorado, Iowa, Maine, Michigan. Montana, Nebraska, Nerada. New Jork (except Long Island), North Dakota, Ohio, Oregon, South Dakota, Utah, Wisconsin, and Wyoming-because of the scarcity of the birds or the closing of the season. The only States in the northern tier which had an open season were New Hampshire. Vermont. Minnesota. Idaho, and Washington, but even in these States the birds were by no means abundant.

On account of existing restrictions as to sale, it is difficult to ascertain the market ralue of quail, but prices adranced considerably during the last century. In 1810. Audubon "records that quail soir? for 12 cents a dozen, and by 1830 the price had increased to 50 cents a dozen. In the season of $1917, \mathrm{t}$ \% years before Congress prohibited their sale entirely in the District of Columbia, they retailed in the markets of $W$ ashington, D. C.. at $\$ 9$ a dozen. Enormous numbers of quail were formerly sold in some of the larger cities, notably San Francisco, where in 1891 it was reported that about 100,000 were sold each year in the market. ${ }^{4}$ This was about 10 years before the sale of quail was prohibited in California. The sale of native quail is row prohibited throughout the United States except in a few counties of North Carolina.

\section{WATERFOWL}

Enormous numbers of waterforl are killed in the United States ENy year during autumn and winter. Formerly they were sold in large quantities in certain markets, notably Boston. New York, Phila-

3 Ornith. Biog., vol. 1, p. 392, 1831.

4 Judd, S. D. (quoting C. P. Streator), The bobwhite and other quail of the United States in their economic relations: Bull. 21, Biol. Survey, U. S. Dept. Agr., p. 48, 1905. 
(elphia, Baltimore, New Orleans, St. Louis, Chicago, and San Fran(isco, but with the progressive adoption of nonsale laws the legal traffic has been greatly restricted until it has now disappeared. With the passage of the Federal migratory-bird law in 1913 and the prohibition of spring shooting, and with seasons shortened to not more than three and a half months in any one State, the number of birds killed has been still further reduced. With the approval on July 3, 1918, of the migratory-bird treaty act, the sale of all migratory game birds was forbidden throughout the United States and Alaska. Notwithstanding all these restrictions several million waterfowl are still shot every year, and these birds furnish an important source of food in nearly every State. In considering the number of birds which have been reported as shot or shipped to market at various times, it is necessary to bear in mind the factors above mentioned and the changes which have been due to the legislation of recent years.

In certain favorable sections waterfowl are again congregating in considerable numbers where formerly the market hunter was accustomed to ply his trade almost without limit. On the Atlantic coast, ducking grounds have made famous the areas on the south side of Long Island, New York; at Barnegat Bay, New Jersey; at the head of Chesapeake Bay, Maryland; and on Currituck Sound. North Carolina. In the Mississippi Valley duck-shooting resorts are almost equally famous in Vermilion Parish and in the delta of the Mississippi, Louisiana ; at Lake Surprise, Texas; in the Sunken Lands of Arkansas; at Reelfoot Lake, Tennessee; on the Illinois River; on the Sandusky marshes in Ohio; on Lake St. Clair and Saginaw Bay, Michigan; in the lake region of Wisconsin; and in southwestern Minnesota. Farther west, the Platte River, Nebraska; the Arkansas bottoms, Kansas; Bear River, Utah; Klamath Lake, Oregon; and the marshes of the Sacramento River, Suisun Bay, Los Banos, and Firebaugh, and certain localities in Orange County and in the Imperial Valley, California, are celebrated ducking grounds. One of the greatest centers for wild fowl in the country is in the vicinity of Great Salt Lake and on the marshes of Bear River, Utah. During the prevalence there of the so-called duck disease, between the years 1910 and 1916, it was estimated that more than 1,000,000 birds perished-an indication of the enormous numbers of birds which frequent these marshes in autumn.

The only system thus far devised of recording accurately or even of estimating the number of ducks killed is that of Minnesota. based on the reports of licensed hunters. In other States all that is possible is to refer to estimates which have been made of the number of birds at certain localities or of the numbers which have been 
shipped to market in some years. The reports of the California Fish and Game Commission estimate that in 1911 approximately $1,000,000$ ducks were killed in that State: ${ }^{5}$ and later (referring also to 1911) the statement was made that " during the season three years ago there were fully 250,000 wild ducks brought into the San Francisco market for sale." " Estimated at the very moderate price of 50 cents each, the ralue of the ducks offered for sale in the city of San Francisco was $\$ 125,000$, while the ralue of the total number killed the same season in the State would be four times as much, or $\$ 500,000$. A more accurate estimate has recently been made in Minnesota, which reports the number of ducks killed in 1919 as 1,804,900, and in 1920 as $1.414,889$ (see p. 20). Although there is at hand no definite information as to the number of waterforl killed in many States, yet enough information is arailable to warrant the statement that in the entire United States the food ralue of the waterforl taken must amount annually to several millions of dollars.

\section{VALUE OF GAME TO THE FARMER.}

The game on the farm is of value to the owner or tenant in several ways. Nearly every farm produces some game which may be hunted in open season, as rabbits, quail, squirrels. or other species, and this has a certain food or recreational value. Upland game birds are often of more use as destroyers of reed seeds or noxious insects than they are as food, but this phase of their economic value has been fully discussed in other publications.

Under favorable conditions the game on the farm may be greatly increased and eren produced artificially, though as yet game farming has made only a beginning in the Uniter States. Pheasants and pheasant eggs have been distributed in certain States and in some cases the persons receiving them hare been successful in rearing the birds, but comparatively little concerted effort has been made by farmers to raise any large number of pheasants, either in cooperation with game departments or for supplying the market. Pheasants, wild turkeys, mallard ducks, black mallards, and wood ducks can be reared on farms, and, commanding higher prices than poultry, might be made even more profitable. ${ }^{\tau}$

Another method of utilizing the game on the farm and of making it render a direct return is to sell or lease the shooting rights. Farms are rery generally posted, but owners and tenants do not as a rule attempt to obtain a direct return by leasing the hunting privileges. How viluable these may be under farorable circumstances is shown

s Trenty-second Bien. Rept., for 1912, p. 22.

${ }^{6}$ Twenty-third Bien. Rept., for 1914, p. 15.

- Directions for raising wild fowl in captivity will be furnished on application to the Biological Survey, U. S. Departmont of Agriculture.

$7956+2 \div$ 
hy the experience of one of the counties in North Carolina, where a fër years ago on most of the farms hunting rights for quail shooting were systematically leased; in 1904 probably two-thirds of all the real-estate taxes outside the towns were paid by receipts from hunting privileges on lands leased for this purpose. In short, the quail crop was made to pay most of the taxes on the farms. The hunting privileges on a number of adjoining farms comprising an area of several hundred or a thousand acres are usually acquired by a single lessee or club, the basis of compensation being a definite rental by the acre for a term of years, with the privilege of renewal. This rental may be based on the tax rate or double this rate.

In sections where it is not feasible to lease lands on a cooperative basis or in sufficient acreage for club preserves, individual landowners who hare quail or other birds on their holdings may still obtain a substantial income. By allowing sportsmen the privilege of hunting on their property and in addition by furnishing them teams. hunting dogs, and the assistance of boys for locating the game, and by proriding accommodations for sportsmen from a distance. the owners will obtain a direct and rery substantial return on any effort expended in increasing the game and prerenting it from being killed off before the season opens.

\section{VALUE OF GAME FROM THE STANDPOINT OF HEALTH.}

In a book entitled "Our National Recreation Parks," Dr. Nicholas senn lays special stress on the ralue of recreation as a restorer of health. ${ }^{8}$

The man who toils with his brain in the bank, the pulpit, the court room, the library. the great mercantile establishments, and last, but not least, at the bedside of the sick or in the operating room, is the one above all others in need of an occasional rest, change of mental activity and surroundings. Men who ignore nature's warnings and appeals for rest, sooner or later are made to pay dearly for their neglect, and only too often mend their ways when it is too late. Brain toil means the prolonged strenuous application of the neurons which preside over functions required in the discharge of professional duties or business transactions. If these functions are overtaxed. brain fatigue is the result.

There is no country in the world that has as many imprudent brain workers as the Cnited States. The unbrilled ambition for fame, influence, and wealth leads to a strenuous life which has shortened the lives and curtailed the usefulness of thousanls of our best professional and business men annually, and there are no indications pointing to an abatement of the inteuse struggle for supremacy in all walks of life. Fortunately, there is no country that can equal our own in the number and attractiveness of places of genuine recreation for those who are in search of mental repose. *** One of the most desirable places for this class of patients is munestionably the Yellowstone lark. * * *

s Senn, Nicholas, Our national recreation parks, pp. 13-16, 71. Chicago, 1904. 
One of the principal motires for the establishment of the Yellowstone National Park was to secure an adrantageous place for the protection and perpetuation of our noble game. *** This large tract of land is one great natural pasture well suplied with the purest water and ample cover for the game in the virgin forest and inaccessible canyons and mountain peaks. It is, in other words, an ideal natural game preserve.

Thus does one of the most eminent members of the medical profession refer to the largest of the national parks, created in part as a game refuge, and recommend persons in search of recreation or relaxation to seek health and strength amid its game and scenery.

Quail shooting, duck hunting, and the pursuit of big game all have their derotees, who, in their farorite sport, find health, relaxation. and inspiration in an outing in the woods or on the water. The lists of upland-game and duck-shooting clubs and the records of nonresident hunting licenses contain the names of statesmen, prominent bankers. business men. and captains of industry. Who in this form of dirersion find health and strength sufficient to warrant large expenditures of capital. The very fact that busy men of affairs are identified with various projects which afford opportunities for hunting game or prospects of increasing it shows that business men find in the pursuit of game a satisfactory return in health as well as in pleasure or relaxation.

\section{RETURNS FROM LICENSE FEES.}

The hunting-license fees now required in most of the States constitute a comparatively modern source of income, dating back only to 189\%. Since that year. when the hunting-license system was in force in only a few States, it has been greatly extended, until now erery State requires nonresidents to obtain licenses, and all but three-Delaware. Mississippi, and North Carolina-make similar requirements of residents. Licenses are issued not only for hunting game. but also for shipping, for breeding. and in some States for selling game. Tags are also supplied for marking each piece of game which is allowed to be sold. Where the tagging system is in operation considerable amounts may be collected, eren though. as in New York, the tagging is limited to certain foreign species or to game raised in captivity.

Owing to the fact that a few States hare not ret required licenses from residents, that most States allow persons to hunt on their own lands without licenses, and that some States combine hunting and fishing licenses, the license returns do not afford an accurate index of the number of hunters. Moreorer, licenses are issued in such different rays and the cost of collecting data raries so much that it is almost impossible to obtain accurate figures showing the actual receipts from this source. Ender these circumstances it is prac- 
ticable only to estimate the total receipts, using as a basis such figures as are available for a normal year.

It was estimated prior to the war that under ordinary conditions the number of persons hunting in the United States was approximately 5,000,000. Granting that 10 per cent of this number were nonresidents, persons exempt from license requirements, and persons hunting without licenses, there were 4,500,000 hunters who should obtain resident licenses. At $\$ 1$ each the gross receipts from this source would amount to $\$ 4,500,000$. Returns from 17 States in 1914 and figures from 17 other States for a normal year prior to the wrir showed that about 15,400 licenses were issued to nonresidents. Of the other 14 States very few issue many nonresident licenses, so 20,000 is a conservative estimate of the number of nonresident licenses issued in an average year. The fees for these licenses varied from $\$ 5$ to $\$ 50$, but most of them ranged from $\$ 10$ to $\$ 25$. If the average fee is considered to be $\$ 15$, the arerage gross receipts from nonresidents would be $\$ 300,000$. The total receipts from licenses should therefore amount to about $\$ 4,800,000$ per annum. Costs of collection, defective laws, and other circumstances tend to reduce this figure considerably, and it is probable that a much smaller amount is actually collected and made available for game protection. Nevertheless, the aggregate for all States is a very large sum.

The returns collected from all the States which issue resident licenses-namely, all except Delaware, Mississippi, and North Carolina (and Florida, from which figures are not arailable)-showeil a total of $3,570,925$ resident licenses, 20,221 nonresident, and 5 t. alien licenses issued in 1919. These figures, however, are somewhat too high, because of the fact that several of the States issue a combined hunting and fishing license and it is impracticable to separate the fishing from the hunting licenses. In some States receipts are sufficient to bear not only the expenses of game propagation but also the cost of maintaining fish hatcheries, and in a few instances large sums collected from hunting licenses, ostensibly for game protection, have been diverted to other purposes by the legislatures.

\section{ESTIMATES OF THE VALUE OF GAME BY STATE OFFICIALS.}

Several States have made estimates from time to time of the value of fish and game within their border's. Under present methods these are necessarily mere approximations and not compiled on a uniform plan. Some include game, others game and fish. and still other's tourist traffic.

The fish and game of Idaho have been estimated to be worth $\leftarrow 1,000,000$ per annum. The Conservation Commission of Louisiana stimates the number of waterfowl killed in a single season at 371,654, "total which includes many of the smaller species, but the value 
of which may be estimated at from $\$ 150,000$ to $\$ 250,000$. Michigan places the annual food ralue of its game animals, birds, and fish at $\$ 500,000$ and the value of the insectivorous birds at $\$ 10,000,000$. New York has estimated the value of game captured in 1918 at $\$ 3,239,277$, representing a total value of $\$ 53,000,000$. Oregon, in 1914 , estimated the ralue of its game at $\$ 5,000,000$. Vermont values its fish and game at $\$ 500,000$ per annum. "equivalent to a dividend at the rate of 4 per cent on $\$ 12,500,000 . "$

The following extracts from the reports of these States show the manner in which the estimates were made:

Idaho.-The fish and game warden of Idaho stated in his report for 1913-14 (pp. 8-9) as follows:

Our fish and game have a large food value. During 1914 there were killed approximately 5,000 deer and the value of the meat is at least 20 cents per pound, whether eaten in camp or on our tables. These deer are worth $\$ 20$ each. Two hundred and fifty elk were killed, worth at least $\$ 80$ each. One hundred mountain sheep and goats were killed, worth $\$ 10$ each. The above figures are food values only; the hides and heads mounted as trophies have a value of many thousands of dollars. ***

When we consider the food value of the fish and game taken from the whole State and in addition the value of the hides and heads of our large game animals, and the number of fur-bearing animals that are taken, a low estimate of these resources is $\$ 1,000,000$ per year. The value to health and happiness from a recreation standpoint is incalculable.

Louisiana.-The Conservation Commission of Louisiana in the report for 1912-1914 included a statistical report (p. 60) of Inspector L. Alberti, showing the combined amount of game received in the markets and taken by sportsmen during the preceding hunting season, based on actual inspection and on market receipts, with an estimated addition for the game killed by sportsmen. The report is for the season 1913-14, from October to February, on mallards. pintails, wood ducks, ringnecks, gray ducks, canvasbacks, redhead;, spoonbills, teal, dos gris or bluebills, poule d'eau, snipe, and geese. with a total estimate of 371,654 .

Michigan.-The Michigan State game, fish, and forestry warden estimated in his report for 1913-14 (p. 6) that the annual food value of the game animals, birds, and fishes taken in the State was $\$ 500,000$, and the value to the farmer of insectivorous and seed-eating birds was $\$ 10,000,000$.

New York.-New York has probably made the most comprehensive estimate of the value of its game resources, based on returns for the year $1918 .^{9}$

In spite of the incompleteness of the returns, it is significant that the total amount of game taken by 208,946 licensed hunters was $1,526,960$, which was an average of more than 7 animals or birds for each hunter. When it is con-

- Carpenter, W. S., New York's annual game dividend: The Conservationist, Albany, N. Y., vol. 4, no. 2, pp. 19-22, February, 1921. 
sidered that many of the licensees did not hunt at all, or were unsuccessful. or failed to report, the actual arerage of the successful hunter is seen to be rery much higher. At the raluations giren in the table. which are based upon current market prices for game or fur legally salable, and upon conservative estimates for all other species. this game was worth a total of $\$ 3,239,277$. This ralue, howerer, was simply the annual dividend, and not the value of the State's capital stock of wild life. If we consider that it was a diridend on the basis of 6 per cent, then the actual capital value of the State's stock of game and fur-bearing animals. on the basis of the 1918 reports of game killed, which are themselves low, is $\$ 53,987,950$.

* * * One of the most important of the conclusions based upon this inrestigation in economic biology can thus be stated as follows :

The game and fur-bearing animals of New York State, if capitalized, are worth not less than $\$ 53,000,000$; they return an annual dividend of more than $\$ 3,200,000$; and they cost the State for their protection and increase the nominal sum of $\$ 182,000$. This cost of protection and increase is thus less than 6 per cent of the annual dividend.

\section{Oregon.-Mr. W. L. Finley, in the report for 1914 of the Oregon} Fish and Game Commission, made the following estimate:

The game of our State is worth approximately $\$ 800,000$ annually from a fooc standpoint. In the neighborhood of 9,000 deer, 150,000 ducks, and 45,000 ) Chines: pheasants are killed annually. When we also consider the numbers of grouse. quail, geese, shorebirds. and other game that are killed, when we estimate that this meat is worth from 12 to 16 cents per pound, whether on the table of the farmer, the mountaineer, or the merchant, it means a big income to our people. * * * A large amount of money is derived annually from the hunting and trapping of our fur-bearing animals. This is a crop that is worth $\$ 100.000$ annually to our State. A large part of the rerenue derired comes directly to the homesteader and the settler who needs it to develop his property. * * * From an economic and business standpoint, the game and other wild creature: of the State are worth $\$ 5,000,000$ annually to us. This is not placing a high estimate on these resources.

Vermont.-The following estimate of the fish and game commissioner of Vermont is contained in the biennial report for 1913-14. pages $3-4$ and 101 :

It will be acknowledged that whenever one brings to the table a mess of fish, regardless of how obtained, it has a market ralue. The same holds true in reference to any form of wild game, which is a luxurious substitute for meat from the butcher. When a member of the family fishes or hunts, has it occurred to the reader to figure up at market prices what he, while indulging in his favorite recreation, contributes to the luxury of the table? *** On this basis an attemnt has been made to figure up the value of all fish and game annually taken in Vermont.

The sum total, conservatively estimated at the lowest market ralue, makes a grand total of over $\$ 502,000$, which, at the savings-bank rate of 4 per cent. is ail annual dividend on $\$ 12,500,000$. In making this estimate the value of insectivorous birds, without the aid of which authorities assert that agriculture would be impossible, has not been taken into consideration. * * * The figures do not include the returns from private preserves in the form of artificial ponds and deer parks. * * * Most of these preserves make mpuluctire land valuable and indirectly raise the value of adjacent property. 
It is safe to say that 20,000 ducks are annually killed in Vermont. While there is no lawful market for them, domesticated mallards in the New York market are worth per pair $\$ 3$ and up, but to be conservative these birds are figured at $\$ 2$ per pair, making the ralue of the season's bag $\$ 20,000$, or an annual dividend at 4 per cent on $\$ 500,000$.

\section{LIMITATIONS ON EXCESSIVE HUNTING.}

\section{BIG GAME AND QUAIL.}

The results of excessive hunting, and particularly hunting for market, are now beginning to be felt in sereral sections of the country which hare been settled for a long time or in which agriculture has

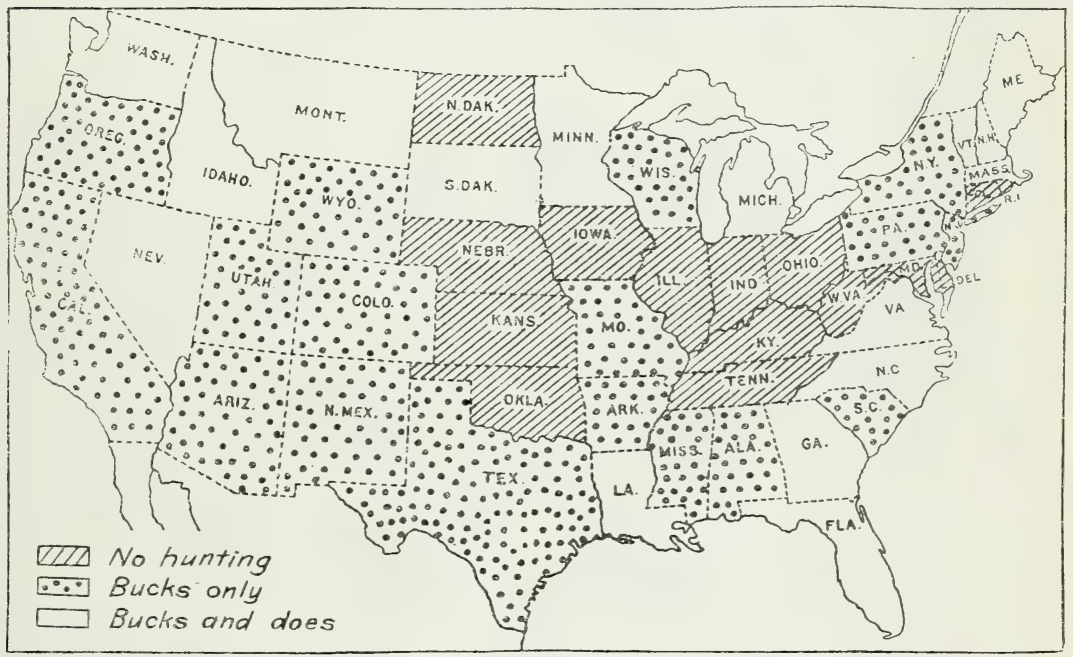

FIG. 1.-Deer hunting in the United States in 1920. In 15 States (shaded area) Lunting was prohibited; in the 33 States which permitted hunting, 17 protected does (dotted area).

been highly dereloped. This is most apparent in the case of big game and quail, the hunting of which is not at present possible in a number of States. Fifteen States were closed to deer hunting in 19:20, as follows: Connecticut, Rhode Island, Delaware, Maryland, and West Virginia in the East; and Ohio, Indiana, Kentucky, Tennessee. Illinois, Iowa, Nebraska, Kansas, Oklahoma, and North Dakota in the Middle West. In Delaware, Ohio, and Indiana deer hare been exterminated for some years; in Illinois, Iowa, Kentucky, and Maryland they are nearly gone; in Connecticut they were abundant several rears ago, but under a law enacted in 1915, allowing the use of shotguns in killing deer injuring crops, several thousand were destroyed and the species greatly reduced in numbers. Of the 33 States which were open does were protected in 17, while bucks and does both could be killed in 16. (See fig. 1.) 
In 1921, owing to the opening of the season in North Dakota and the protection of does in Michigan, Montana, Nevada, North Dakota, South Dakota, Vermont, and the greater part of Washington, these figures are changed as follows: No deer hunting in 14 States; does protected in 23 States; hunting bucks and does permitted in 11 States.

Fifteen States-Maine, New York (except Long Island), Ohio, Michigan, Wisconsin, Iowa, Nebraska, North Dakota, South Dakota, Montana, Wyoming, Colorado, Utah, Nevada, and Oregon (except a few counties) -during 1920 were closed to quail hunting also. (See fig. 2.) This is partly due to the great reduction in the number of birds, and partly to the fact that in the Northern States quail are not present in sufficient numbers to permit them to be hunted. The

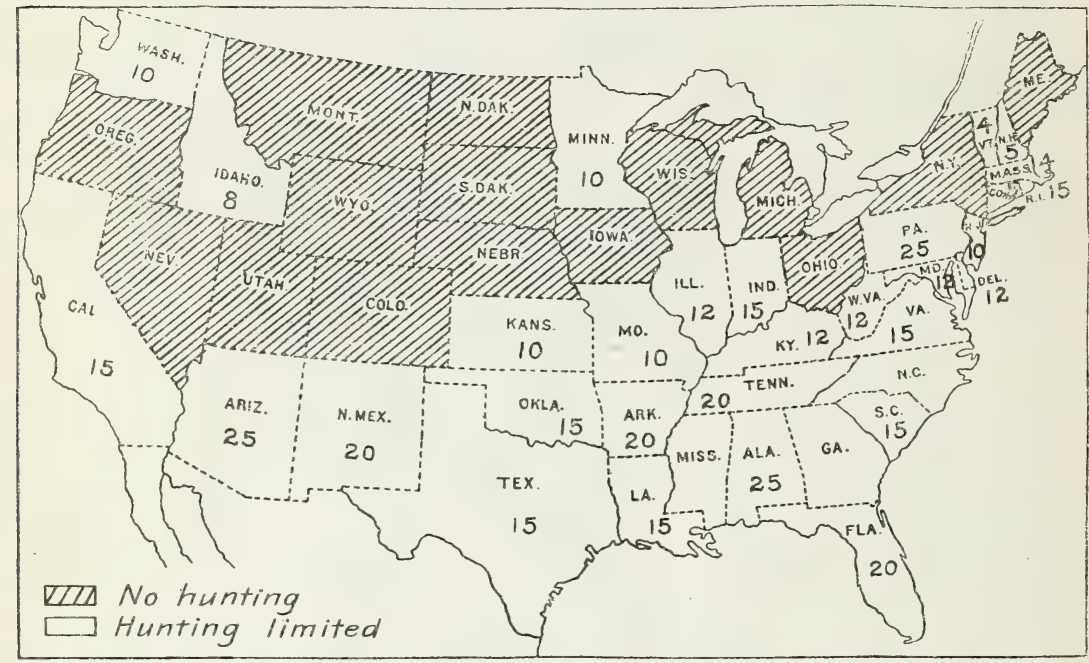

FIG. 2.-Quail hunting in 1920. The shaded portion shows the area in which hunting was prohibited. In the 33 States with open seasons, the numbers indicate the daily bag limits.

open seasons on quail in 1920 in the 33 other States varied in length from 10 days to 4 months. The daily bag limit on quail raried from 4 to 25. Fifteen States had a bag limit of 12 or less and 15 States of 15 to 25. Georgia, Mississippi, and North Carolina apparently had no State limits. In Tennessee the limit of 20 included birds and small game of all kinds.

It is not surprising that States like Maine, Michigan, Wisconsin. North Dakota, Montana, and Wyoming, which are for the most part outside the normal range of quail and in which the birds are likely to be killed off during severe winters, should not be able to obtain sufficient stock to allow general hunting, but it is remarkable that States like Iowa. Nebraska, and Ohio, which formerly were in the 
center of abundance of these birds, no longer afford quail hunting. Kansas was the pioneer State in attempting to curtail traffic in game birds by prohibiting export of quail in 1876. Iowa, in 1878, attempted to restrict excessive killing by establishing a daily bag limit. The Kansas law, however, did not remain in force very long. In the nineties southern Kansas was the center of the shipment of quail for propagation, and thousands of birds were shipped from the vicinity of Wichita to various States east and west, and also to foreign countries. In 1903 the State found it necessary to close the season on quail in 19 counties; in 1905 to extend the protection three years longer in 14 of these counties; and in 1913 to give quail protection in all the counties for a period of fire years. Following this

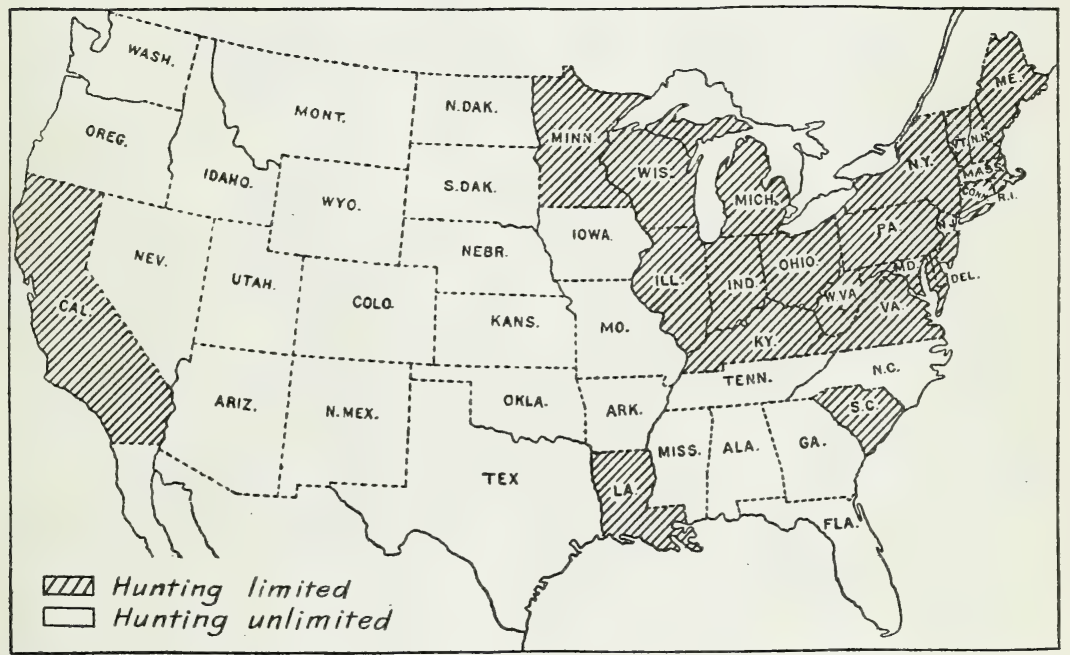

Fig. 3.-Rabbit hunting in 1920.' In 23 States, chiefly in the East (shaded area), short open seasons were provided. In the remainder of the country hunting was unlimited.

example, Idaho, Iowa, and Ohio in 1917 enacted laws protecting quail throughout the year.

That deer hunting should no longer be possible in the great agricultural States in the Middle West is perhaps not surprising, but when quail shooting also is eliminated, conditions become serious for the sportsman. Three States in this section-Ohio, Iowa, and Nebraska-now have neither deer hunting nor quail shooting. In Ohio there are possibly 265,000 sportsmen, in Iowa about 105,000, in Nebraska about 65,000. Nearly 435,000 sportsmen of these three States are deprived of any big-game hunting or quail shooting unless they go elsewhere, and are forced to confine their hunting mainly to rabbits (see fig. 3) and waterfowl. 


\section{BAG LIMITS.}

Daily and seasonal bag limits are established primarily to restrict the amount of game which an individual may legally kill under the most favorable circumstances. While the object of such restriction is to prevent undue destruction when game is abundant, it is not often realized how liberal these limits are in the case of certain kinds of game. In many States a resident is limited to one deer a season and the fee for a license to hunt this deer is usually $\$ 1$. Unless the deer is a small doe or a fawn of the year (the killing of which in some States is prohibited), it will dress at least 100 pounds, and for his $\$ 1$ license the hunter has authority to secure at least 100 pounds of the best wild meat. Under the same license, or in a few States under a similar bird license costing $\$ 1$, the hunter is allowed to kill a certain number of game birds. The limit for ducks is ordinarily 25 birds a day, and with fair success in hunting such of the larger ducks as mallards, black mallards, canvas-backs, or broadbills, in three or four days a hunter can obtain 100 pounds of birds, or the equivalent in weight of a season's limit of big game, while if he succeeds in getting limit bags he may secure this amount in even less time. As only a few States have placed limits on the number of rabbits which may be killed in one day, a fair amount of fresh meat can be obtained by hunting rabbits under a $\$ 1$ license, provided advantage is taken of favorable weather during the open season. In short, the quantity of wild meat, stated in pounds, which a hunter can reasonably expect to obtain under favorable circumstances and at a nominal cost so far as the State license is concerned. is very considerable.

\section{RECORDS OF GAME KILLED.}

It is rather remarkable that thus far so little progress has been made in such a fundamental subject as making an enumeration of the game or even in collecting estimates of the game annually killed. Statistics are indispensable, for without a knowledge of the quantity of game killed each year it is impossible to tell except in the most general way whether the stock is increasing or decreasing. Lack of data of this kind may perhaps be explained by the fact that until recently it was impossible to tell how many hunters there were, but since the adoption of the license system it has been possible to approximate the number of persons hunting and also to provide the means of collecting much needed information concerning the effect of hunting on the game.

Several States have undertaken to ascertain the amount of game actually killed, but very few have made more than a beginning, and 
the methods of collecting such information vary as widely as the methods for determining the value of game resources.

Two States-Maine and New York-for several years kept records of the big game transported by rail: Maine, by checking shipments at Bangor and Portland since 1894, and New York, by enlisting the aid of the transportation companies which bring deer from the Adirondacks. These returns, of course, do not include the large numbers of animals consumed on the ground and never brought out of the woods. During the 20 years from 1894 to 1913, 3,434 moose and 65,305 deer were transported by rail in Maine. This source of information is less valuable than formerly, since it is now possible for private individuals to transport large numbers of deer in automobiles.

Vermont is a pioneer in recording the total number of deer actually killed, having made annual counts ever since the opening of the deer season in 1897 (see p. 38). This is probably one of the most accurate records in the country and is made by collecting data from wardens, postmasters, and from hunters themselves, not only as to numbers but as to the weights of the heavier animals.

Massachusetts has for 11 years recorded the number of deer, and since 1914 the number of pheasants killed.

Number of deer and phersants hilled in Massachusetts during the open seasons since $19100^{1}$

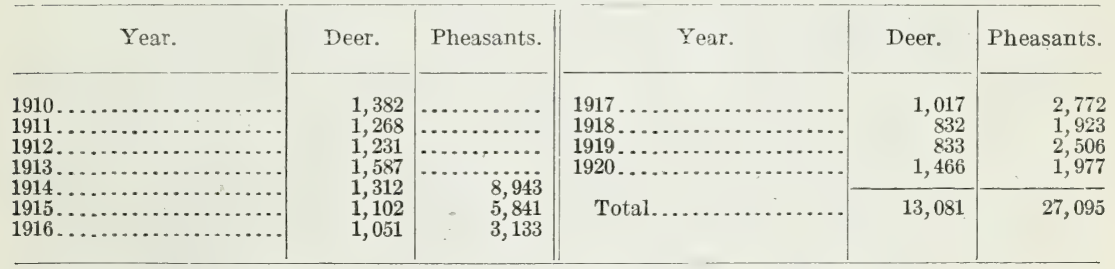

1 Ann. Rept. Div. Fish and Game, Mass., 1920 pp. 40-46.

New Jersey (see p. 37) annually records the number of deer killed during the four or fire days of the open season, and Minnesota and Wisconsin recorded the number killed during 1919-20. The Fish and Game Commission of California has published in some detail the figures regarding the number of deer annually killed since 1911, and has estimated on the basis of shipments received at San Francisco and other points the number of ducks killed during the open season in 1911. In Oregon, also, the commission has published some figures regarding the number of deer killed.

For most of the Western States the Forest Service has for several years collected figures as to the numbers of big game killed on the various national forests, and as these reservations include most of 
the big-game areas, the statistics thus obtained are the best arailable for the Rocky Mountain States.

About 1910 Louisiana inaugurated an elaborate system of collecting figures from local wardens as to the number of each kind of game killed in their districts, but these figures were nerer published in detail and the totals were so large as to indicate that they were orerestimates in some cases. Pennsylrania published the following comprehensire statement of the total amount of game killed in the State in 1919 :

Game killed in Pennsylvania, season of 1919.

[Individual and total weights estimated.]

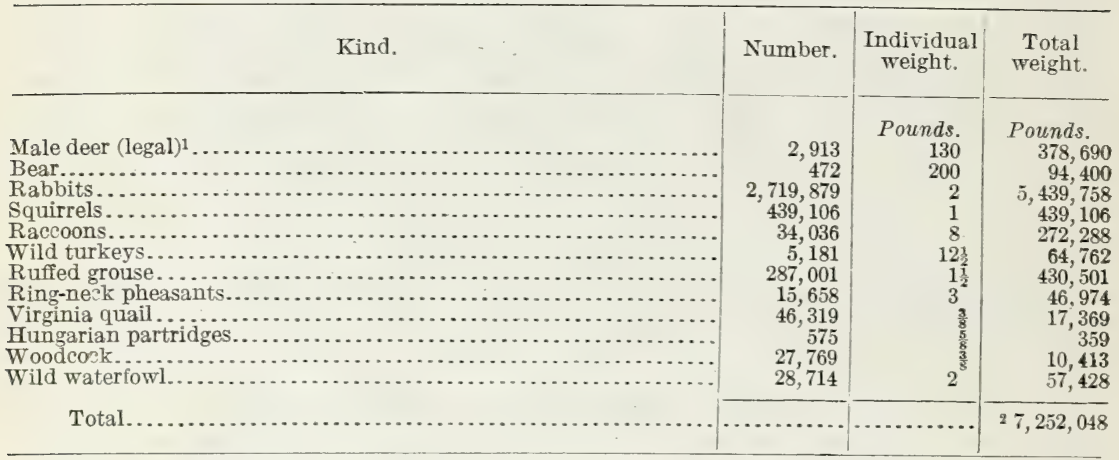

1 There were also 119 male fawns and 207 does illegally killed during the season.

2 Not including 23,786 shorebirds of various kinds nor 175,000 blackbirds killed.

Minnesota in 1919 and 1920 required holders of hunting licenses to make written reports to the commission within 30 days after the expiration of the licenses, showing the kind and the number of bircls or animals taken thereunder. These returns have brought together some interesting figures, which are summarized as follows:

Game killed in Minnesota, 1919 and 1920.2

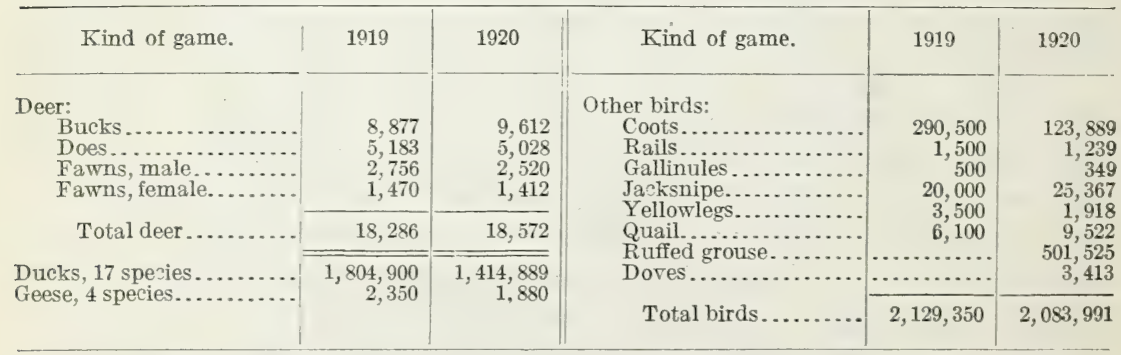

${ }^{1}$ Condensed from paper by Carlos Avery, Minnesota's game census: Fins, Feathers, and Fur, No. 25, pp. 9-11, March, 1921.

Virginia is the most recent State to undertake a surrey of its game, and through its department of game and inland fisheries has pub- 
lished a report based on data obtained from game wardens and special observers showing in detail the amount and value of game killed in each county during the season of 1920. In most cases the returns are marked so as to show whether the game is increasing or decreasing. A careful study of the figures brings out several interesting facts, as, for example, the section in which certain kinds of game are most abundant. In the case of deer more than 90 per cent were killed in the southeastern part of the State, while nearly 80 per cent of the bears were obtained in Nansemond and Rockingham Counties. Following are the totals for each kind of game killed:

Game killed in Tirginia in 1920.

\begin{tabular}{|c|c|c|c|c|c|}
\hline Kind of game. & Number. & Value. & Kind of game. & Number. & Value. \\
\hline 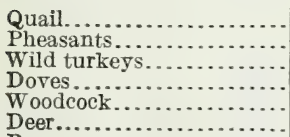 & $\begin{array}{r}166,570 \\
5,175 \\
4,122 \\
8,410 \\
3,105 \\
691\end{array}$ & $\begin{array}{r}\$ 83,285.00 \\
6,468.75 \\
12,366.00 \\
2,102.50 \\
1,552.50 \\
17,275.00\end{array}$ & 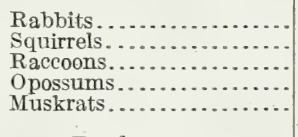 & $\begin{array}{r}293,625 \\
108,535 \\
15,611 \\
43,436 \\
70,430\end{array}$ & $\begin{array}{r}\$ 146,812.50 \\
21,707.00 \\
16,833.00 \\
43,436.00 \\
70,430.00\end{array}$ \\
\hline Bears........... & 117 & $3,510.00$ & Total. & & $455,778.25$ \\
\hline
\end{tabular}

The most comprehensive work in connection with game enumerations has been done by the Conservation Commission of New York. In the winters of 1915 and 1916, and subsequently, when the deer were yarded, every game protector was required to report on the number seen in his territory, based on observations on the deer in the yards, their tracks, and such other data as were available. Monthly reports were required at other seasons, and as a result of the investigation, extending over sereral years, the deer population of the State in 1919 was found to be approximately 50,000. Other in restigations relative to grouse, woodcock, and waterfowl also were made. During 1919 applicants for hunting licenses were required to file with their applications a statement of the numbers and kinds of game animals and birds killed during the previous year and were furnished with a card on which to keep an itemized record of the game killed under the new license. It is necessary to return these cards before any subsequent license is issued. In this way the license system is made the means of obtaining more nearly complete and accurate statistics than have hitherto been available. As stated in an interesting report by the conservation commissioner in a paper read before the International Association of Fish, Game, and Conservation Commissioners in 1918:

The paramount feature of New York's game census system is that it is founded upon definite observation and demonstrable facts. It should enable us to keep every wise law upon our statute books and to bring about changes 
only as rapidly as actual changes in the conditions of wild life justify modification of the law. ${ }^{10}$

The returns for 1918 have recently been summarized by W. S. Carpenter, secretary of the commission, and the results made available, as shown in the following table:

Game taken in New York in 1918.

\begin{tabular}{|c|c|c|c|c|c|c|c|}
\hline Species. & $\begin{array}{c}\text { Total } \\
\text { killed. }\end{array}$ & $\begin{array}{l}\text { Indi- } \\
\text { vidual } \\
\text { value. }\end{array}$ & $\begin{array}{c}\text { Total } \\
\text { value. }\end{array}$ & Species. & $\begin{array}{c}\text { Total } \\
\text { killed. }\end{array}$ & $\begin{array}{c}\text { Indi- } \\
\text { vidual } \\
\text { value. }\end{array}$ & $\begin{array}{c}\text { Total } \\
\text { value. }\end{array}$ \\
\hline Cottontail rabbi & 465,590 & $\$ 0.50$ & $\$ 232,795.00$ & Greater yellowlegs.. & 3,556 & $\$ 0.50$ & $\$ 1,778.00$ \\
\hline Muskrat. . & 399,938 & 1.50 & $599,907.00$ & Lesser yellowlegs... & 2,848 & .50 & $1,424.00$ \\
\hline Skunk...... & 187,703 & 4.00 & $750,812.00$ & Gray fox.............. & 2,476 & 2.00 & $4,952.00$ \\
\hline Gray squiriei. & 115,013 & .50 & $57,506.50$ & Coot.. & 1,974 & .50 & 987.00 \\
\hline Duck......... & 109,663 & 2.00 & $219,326.00$ & Goose. & 1,380 & 3.00 & $4,140.00$ \\
\hline Grouse or partridge & 41,757 & 2.00 & $83,514.00$ & Rail.. & 1,328 & .50 & 664. \\
\hline Snowshoe rabbit... & 36,170 & 1.00 & 36,17000 & Golden plover...... & 1,214 & .50 & 607.00 \\
\hline Pheasant.... & 35,855 & 3.00 & $107,565.00$ & Black-bellied plover & 1,045 & .50 & 522.50 \\
\hline Rascoon. & 25,349 & 5.00 & $126,745.00$ & Sable, or marten... & 823 & 4.00 & $3,292.00$ \\
\hline Woodcosk & 19,249 & 2.00 & $38,498.00$ & Otter.............. & 591 & 25.00 & 14,775 . \\
\hline Red fox... & 15,156 & 15.00 & $227,340.00$ & Fisher. & 396 & 25.00 & $9,900.00$ \\
\hline Wilson snipe, or & & & & Brant. & 241 & 3.00 & 723.00 \\
\hline jacksnipe......... & 11,325 & .50 & $5,662.50$ & Gallinule. & 216 & .50 & 108. 00 \\
\hline Black squirre & 11,028 & .50 & $5,514.00$ & Bear.. & 189 & 25. 00 & 4,725 . \\
\hline Quail.. & 8,999 & 2.00 & $17,998.00$ & Bobcat...... & 159 & 10.00 & $\mathbf{1}, 590$. \\
\hline Mink... & 8,917 & 6.00 & $53,502.00$ & Sora................ & 82 & .50 & 41.00 \\
\hline Deer (bucks).... & $\begin{array}{l}8,437 \\
8,293\end{array}$ & 75.00 & $\begin{array}{r}4,218.50 \\
621,975.00\end{array}$ & Total & $1,526,960$ & & $3,239,277.00$ \\
\hline
\end{tabular}

In Canada several of the Provinces have attempted to collect statistics by requiring a return from hunters holding big-game licenses. This system has been in operation in Manitoba since 1905, in Alberta and Nova Scotia since 1907, in New Brunswick since 1908, and in British Columbia since 1913, and has furnished valuable figures regarding the numbers of big game killed. Experience has shown that ordinarily at first a large proportion of the licensees fail to make the return and that it is almost impossible to obtain figures from delinquents who are nonresidents or from residents who have moved or left the Province. Following are the figures for Nova Scotia :

Big game killed in Nova Scotia, 1908 to 1920.

[From report game commissioner for 1920, pp. 22-30.]

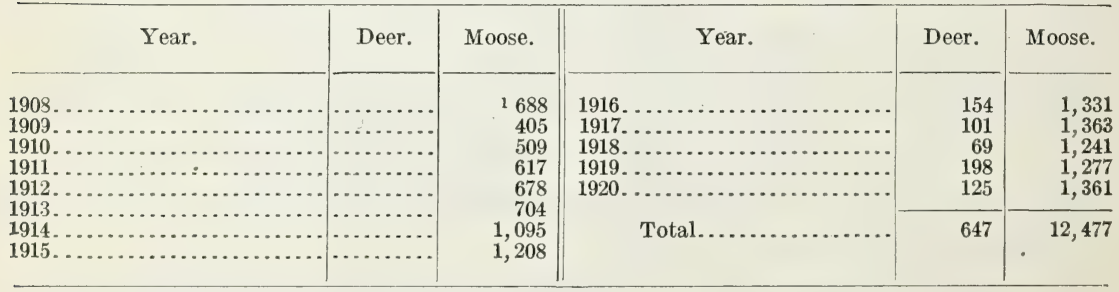

${ }^{1}$ Includes 240 cows.

10. I'ratt, George D., Checking up New York's game resources: Bull. Amer. Game Protective Assn., vol. 7, no. 4, pp. 11-14, October, 1918. 
One of the most complete records of this kind is that maintained by the Province of Alberta. Under a provision inserted in the law of 1907 , each resident to whom a big-game license was issued was required to return the license to the Department of Agriculture immediately after the close of the season, accompanied by an affidavit showing the number of animals killed. Failure or neglect to return the license within 30 days after the end of the season constituted a violation of the game law and was ground for the refusal of a license in future. (The latter provision seems to have been modified or repealed in recent years.) At first these provisions were not generally known or strictly enforced, and consequently the returns fell far short of the actual number of animals killed, but as time went on they became more generally understood and the returns were fairly accurate though doubtless always somewhat below the actual number. The records obtained under this law for the 12 vears $1907-18$ are shown in the accompanying table, which also gires for comparison the total number of big-game licenses issued. The limits in Alberta have usually been one deer, moose, and caribou, and two antelope, sheep, and goats, a season.

Big game killed in Alberta, 1907 to 1918.

[From Ann. Rept. Dept. Agr. Alberta for 1919, p. 122.]

\begin{tabular}{|c|c|c|c|c|c|c|c|c|c|}
\hline Year. & Deer. & Elk. & Moose. & Caribou. & $\begin{array}{l}\text { Ante- } \\
\text { lope. }\end{array}$ & $\begin{array}{l}\text { Moin- } \\
\text { tain } \\
\text { sheep. }\end{array}$ & $\begin{array}{l}\text { Moun- } \\
\text { tain } \\
\text { goats. }\end{array}$ & $\begin{array}{l}\text { Total } \\
\text { killed. }\end{array}$ & $\begin{array}{l}\text { Total big- } \\
\text { game } \\
\text { licenses. }\end{array}$ \\
\hline $\begin{array}{l}1907 \ldots \ldots \\
1908 \ldots \ldots \\
1909 \ldots \ldots \\
1910 \ldots \ldots \\
1911 \ldots \ldots \\
1912 \ldots \ldots \\
1913 \ldots \ldots \\
1914 \ldots \ldots \\
1915 \ldots \ldots \\
1916 \ldots \ldots \\
1917 \ldots \ldots \\
1918 \ldots \ldots \\
\end{array}$ & $\begin{array}{r}59 \\
125 \\
299 \\
540 \\
619 \\
768 \\
908 \\
1,388 \\
692 \\
560 \\
705 \\
828\end{array}$ & 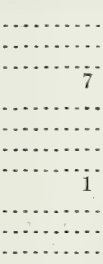 & $\begin{array}{r}14 \\
37 \\
86 \\
184 \\
305 \\
425 \\
865 \\
1,335 \\
1,116 \\
849 \\
1,026 \\
900\end{array}$ & $\begin{array}{r}5 \\
8 \\
30 \\
40 \\
56 \\
78 \\
34 \\
28 \\
-43 \\
45\end{array}$ & $\begin{array}{r}49 \\
45 \\
89 \\
126 \\
101 \\
105 \\
119 \\
\ldots . \\
\ldots\end{array}$ & $\begin{array}{r}40 \\
54 \\
49 \\
90 \\
65 \\
78 \\
110 \\
83 \\
57 \\
76\end{array}$ & $\begin{array}{l}38 \\
46 \\
56 \\
58 \\
42 \\
61 \\
40 \\
26 \\
37 \\
43\end{array}$ & $\begin{array}{r}122 \\
207 \\
557 \\
965 \\
1,160 \\
1,486 \\
2,055 \\
2,940 \\
1,993 \\
1,546 \\
1,868 \\
1,892\end{array}$ & $\begin{array}{r}450 \\
536 \\
1,179 \\
2,021 \\
2,955 \\
3,988 \\
5,670 \\
7,326 \\
5,959 \\
4,185 \\
4,852 \\
4,953\end{array}$ \\
\hline Total. & 7,491 & 8 & 7,142 & 367 & 634 & 702 & 447 & 16,791 & 44,074 \\
\hline
\end{tabular}

\section{ENUMERATIONS OF GAME.}

After securing returns for statistics of big game and game birds annually killed, the next step is to estimate the total stock of each species within a certain State or area. Except for a few species of big game which have been reduced almost to the point of extermination, notably buffalo, elk, and antelope, it has been impracticable hitherto to obtain any comprehensive estimates of this kind.

The buffalo is now in a state of semidomestication, and it is a comparatively simple matter to ascertain its total numbers. Thirteen counts have thus far been made in the following years: 1889,1903 , 
1908, 1910, 1911, 1912, 1913, 1914, 1916, 1918, 1919. 1920, and 1921. Briefly, they show that the total number of buffalo in existence has increased in 32 years from 1.091 in 1889 and 1.753 in 1903 to about 9,300 on January 1, 1921. These figures do not include the wood bison of Canada. The details of the first count were published in 1889 in Hornaday's "Extermination of American Bison" (p. 525$)$; the second by the National Zoological Park; and the others in the annual reports of the American Bison Society.

In the case of antelope the Biological Survey published an estimate for the year 1908, based on the best figures then obtainable, showing a total of $1 \overline{7}, 000$ in the United States, or, adding those in Canada, a total of less than 20,000 north of Mexico. ${ }^{11}$

An estimate of the number of moose, made by the Biological Survey for 1910, showed about 3,050 in the northern Rocky Mountain region-in Idaho, Montana, and Wyoming. ${ }^{12}$

For mountain goats the Forest Serrice officials estimated that in 1910 the total number in the State of Washington, exclusire of the Mount Rainier National Park, was about 1.700, of which 700 were on the west slopes and 1,000 on the east slopes of the Cascades.

The New York Conserration Commission estimates the total number of deer in that State at about 50,000. No other State has attempted to collect the necessary data in as comprehensive a manner.

From the foregoing partial estimates it is possible to approximate roughly the total number of big game other than deer in the United States. The figures in the following table should be regarded merely as maximum approximations and not in any sense accurate estimates.

Estimates of total number of big game other than deer in the Enited states.

\begin{tabular}{|c|c|c|c|c|c|}
\hline Kind of game. & 1918 & 1920 & Kind of game. & 1918 & 1920 \\
\hline \multirow{2}{*}{ 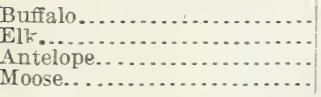 } & \multirow{2}{*}{$\begin{array}{r}2,700 \\
72,000 \\
10,000 \\
6,000\end{array}$} & \multirow{2}{*}{$\begin{array}{r}3,400 \\
52,000 \\
7,500 \\
7,000\end{array}$} & 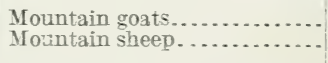 & $\begin{array}{r}6,000 \\
11,000\end{array}$ & $\begin{array}{r}6,000 \\
10,000\end{array}$ \\
\hline & & & Total. & 107,700 & 85,900 \\
\hline
\end{tabular}

This total of about 86.000 for 1920 covers only the big game south of the northern boundary of the United States. latitude $49^{\circ}$, and does not include the game of Alaska or of any part of Canada. Consequently, more than 50 per cent of the buffalo of Yorth America are omitted from the statement, as are a considerable number of eik, the great herds of moose and caribou, and thousands of mountain sheep. Of the 3.400 buffalo, 1.032 are in Gorernment herds, 111

${ }_{11}$ Palmer. T. S., Progress of game protection in 1908: Fearbook, U. S. Dept. Agr., 1908, p. 582, 1909

12 Palmer, T. S., and Henry Oldys, Progress of game protection in 1910 : Biol. Surr. Circ. 80, p. $11,1911$. 
are owned by States, and the remainder are in private hands. The elk are chiefly confined to the northern Rocky Mountain region in the vicinity of the Yellowstone National Park, and in Arizona, Colorado, Idaho, Washington, and California. Of the antelope less than 500 are on Government game preserves and most of the others are in Montana, Wyoming, New Mexico, Nevada, and eastern Oregon. Moose are restricted to Maine, Minnesota. Wyoming, Montana, and Idaho. Mountain sheep are more generally distributed, the larger numbers now being found in Colorado, Montana, Wyoming, Arizona, and California. Mountain goats are confined to the Cascade region in Washington and to the mountains in western Montana and eastern Idaho.

It is of course impossible to estimate accurately the value of this big game. Some of the elk, moose, and sheep belong to species found nowhere else in the world and are now represented by small herds. Unlike most things which have a definite ralue, wild game can not always be replaced when it is exterminated orer an area. No market value in the ordinary sense of the term can be placed upon such animals. If buffalo should be valued at $\$ 200$, antelope and moose at $\$ 100$, elk at $\$ 75$, and sheep and goats at $\$ 30$ each (all conservative figures, at least for animals for propagating purposes), the total ralue of the big game other than deer would be not less than $\$ 5,000,000$. Deer are much more abundant than any of the other kinds of big game, and with the figures arailable it is probably safe to estimate that their value is at least twice that of other big game. This would gire a value of $\$ 10,000,000$ for deer and a total value of at least $\$ 15,000,000$ for all the big game in the United States, exclusive of Alaska.

\section{METHODS OF INCREASING GAME RESOURCES.}

Of the various methods of increasing game resources which have been suggested or put into practice in the United States, four merit special notice, namely, protecting game, establishing refuges, restocking depleted areas, and breeding on game farms.

The simplest method, and usually the first adopted, consists merely in protecting the native stock of game so as to allow it to increase naturally. This is done through legislation, by defining the seasons for hunting, regulating methods of capture, and limiting the amount that may be taken or the purpose for which it may be used; and through administration, by enforcing the various provisions of law. All of this work, which has occupied most of the attention of game departments, is in a certain sense negative, since, without any constructive action in the direction of increasing the stock, it merely seeks to prevent undue destruction. 
In establishing game refuges the protective method is carried a step further by suspending all hunting on a giren area and allowing the game to multiply without harresting an The surplus is allowed to orerflow the surrounding region and thus improre hunting on the lands adjoining the refuge. Then refuges of adequate size are properly selected and well stocked. this method prores rery satisfactory. On the other hand, poaching is likely to occur. and, furthermore, the game. being subject to disease. to depredations of predatory animals. or to unfarorable climatic condition: does not always increase at the rate anticipated.

By resorting to restocking. the first positive step is taken in directly increasing the amount of game by artificial means. This is done either br the transfer of natire species from adjoining or distant regions or by the introduction of foreign species. Restocking has the adrantage of arousing general interest. improring public sentiment toward game protection in a region. and enlisting the support of many persons who otherwise would take little or no interest in game conserration. It requires considerable funds, though money is usually more easily obtained for restocking than for warden serrice. The results, howerer, are not alwars satisfactory. In fact. the percentage of failures is much larger than in the case of experiments with refuges. mainly because many attempts at restocking hare been ill-adrised-species not adapted to a region hare been introduced and insufficient attention has been giren to details of capture, handling, and feeding.

On the theory that game can be produced like poultry or domestic stock. the game farm has been heralded in some States as the solution of the problem. It is sometimes asserted that. giren so many dollars, so mant pheasants mar be produced for liberation. Simple as this method mar seem. it has prored more difficult and more expensire than any of the others mentioned. and in sereral instances expense and lack of initial success hare resulted in loss of interest on the part of the public and hare ended. temporarily at least. in the abandonment of the project. Artificial game propagation is still in an experimental stage. and the kinds of birds which can be produced in large numbers with any degree of certainty are at present rers limited. Failures are due most frequently to initial inrestments on too large a scale. to deroting time and money to birds the propagation of which is still in an experimental stage. and to attempts to produce too much stock in a limited time.

\section{PROTECTION.}

In the conservation of game in the United States more attention has been given to protection than to any other method. Probably three-fourths of the funds and of the effort have been expended in 
this direction, mainly by regulating seasons and methods of hunting, limiting the amount of game which may be killed in a specified time, prohibiting export and sale, and providing means for administration chiefly through a system of licenses.

The first law regulating seasons and prohibiting export was passed nearly 250 years ago, in 1677 , in Connecticut. Other forms of protection have been more recent. The first laws placing limits on the amount of game to be killed were enacted less than half a century ago, in 1878, in Iowa. Laws prohibiting the sale of all protected game are of as recent date as 1887 in Wisconsin, and were passed 10 years later in Kansas, Michigan, New Mexico, and Texas.

In regulating seasons certain principles are generally considered fundamentally important, but their application has been strongly resisted. Among these are the prohibition of summer shooting-that is, during the breeding season; the prohibition of spring shooting, while birds are on their way to the breeding grounds; and the protection of females of big game, particularly in the case of deer.

SUMMER SHOOTING.

Summer shooting has been most destru tive in the case of woodcock, squirrels, and shorebirds. Owing to the fact that the woodcock breeds early, that the young are well developed before autumn, and that the birds migrate early, the custom developed years ago of opening the season in midsummer, in some States as early as July 4. This practice prevailed for many years and only recently has July and August woodcock shooting been abolished.

Squirrel shooting in summer has not yet been entirely stopped. Of the 38 States which protected squirrels in 1920, 6 permitted summer shooting as follows: Arkansas, beginning May 15; Missouri and Tennessee, June 1; Illinois and Kentucky, July 1; and Indiana, August 1.

Spring and summer shorebird shooting persisted along the Atlantic coast in some States, until the passage of the migratory-bird law in 1913. The birds were shot not only on the northward flight in May but also as soon as they reappeared early in July. Under the present Federal regulations the season on such shorebirds as may be hunted opens as follows:

August 16 in the coast States of New England, and in New York, New Jersey, Delaware, Maryland, and Virginia;

September 1 in the District of Columbia. North Carolina. South Carolina, Tennessee, Arkansas, Oklahoma, Texas, New Mexico, Arizona, California, and Alaska;

September 16 in Vermont, Pennsylvania, Ohio, West Virginia, Kentucky, Indiana, Michigan, Wisconsin, Illinois, Missouri, Iowa, Minnesota, North Dakota. South Dakota, Nebraska, Kansas, Colorado, Wyoming, Montana, Idaho, Nevada, and that portion of Oregon and Washington lying east of the summit of the Cascade Mountains; 
October 1 in Utah and in that portion of Oregon and Tashington lring west of the summit of the Cascade Mountains:

Vomber 1 in Georgia. Florida. Alabama. Mississippi. and Louisiana.

\section{SPRIYG SHOOTIXG.}

Yotwithstanding the well-recognized fact that birds should not be killed during the mating season or while on their way to their breeding grounds, it has proved one of the most difficult problems of game protection to put an end to the practice of shooting waterforl and other migratory birds in spring. The first law prohibiting spring shooting was passed 75 rears ago. in 15 46 . in Rhode Island. but for half a century the morement made little progress. Duringr the last 20 rears a number of the Yorthern States hare prohibited waterforl shooting in spring. but the difficulty of eradicating the practice in some sections immediately became erident with the enactment of the migratory-bird lam in 1913. No regulation was so strenuously opposed as that prohibiting shooting in spring. particularly in some of the States of the Middle West. The beneficial effects of diminishing if not entirelr eliminating spring slaughter became apparent almost immediately and no feature of Federal protection of migratory birds has done more to increase the number of waterfowl than that prohibiting shooting when birds are on their northward migration.

PROTECIIYG FEMAIES OF BIG GAME.

The importance of preserving the breeding stock by protecting females has long been recognized. With those species of big game in which the sex is easily distinguished, as in deer, elk, and moose. this can readil be accomplished br restricting the hunting to males. California as early as 15s.3. protected does. and Colorado a fer rears later adopted the same policy. In the case of moose. it has been the practice to protect coms erer since Maine inaugurated it in 1691 . The beneficial results of such a policr have since been demonstrated in some of the Prorinces of Canada. At present moose hunting practicalls everywhere is restricted to bulls.

In the case of deer, legislation for the protection of does has made gradual though rather slow progress. and in some States it has met with strenuous objection. In 1920 about half the States which permitted deer hunting protected does at all seasons. More specifically. 3:3 States enjored deer hunting. and of these. 17 and the Territory of Alaska protected does (see map. fig. 1) : and. as alreadr stated (p. 16). this number was increased in 1921 to 23 States. exclusire of Alaska.

Doe laws are important not only in conserring the breeding stock of deer but also in protecting human beings. since the simple expedient of requiring a hunter to ascertain before shooting whether the 
animal at which he aims has horns has been the means of saving many a human life. Comparatively fer deer-hunting accidents occur in States which have doe laws, but notwithstanding this fact, such important deer-hunting States as Maine and Minnesota still allow the indiscriminate killing of bucks and does. In States like Pennsylvania and Vermont, where does hare been protected for a number of years (although Vermont allowed killing for a time), the results hare been so beneficial that the policy has gained general approral.

\section{ESTABLISHING GAME REFUGES.}

To replenish and increase their game resources, many of the States. by establishing State game preserves and refuges, hare encouraged game animals and birds to breed under natural conditions. These reserrations are (a) public hunting grounds or shooting preserves; and $(b)$ game preserves or refuges. In addition, many States have experimented in game farms. Public hunting grounds, consisting of State lands where game is protected throughout the greater part of the year and where the public is allowed to hunt in the open season, hare thus far been provided only in New York, Pennsylvania, Maryland, Michigan, and Louisiana. State game preserves have been established in nearly two-thirds of the States, including half of those east of the Mississippi River and all of those west of that river except Arkansas, Missouri, Nevada, and Texas.

PUBLIC HUNTING GROUNDS.

The most notable examples of public hunting grounds are the Adirondack Preserve, in New York; the Susquehanna Flats, in Maryland; the State forests in Pennsylvania; and the recently established Pass a Loutre shooting grounds in Louisiana.

The Adirondack Preserve now includes timber or cut-over lands in northern New York which have been acquired by the State. These lands. set aside primarily for forestry purposes and for the protection of the water supply, are open to the public for hunting during the open season and furnish the most extensive public hunting grounds in the country. Most of the deer hunting and much of the best grouse shooting in New York may be found within the Adirondack Preserve. This preserve has also been stocked with elk and other animals, but these species are rigidly protected and there is no open season during which they may be hunted.

The shooting grounds on the Susquehanna Flats, at the head of Chesapeake Bay, Md., constitute the oldest of the State game reservations, the regulations for the protection of the waterfowl having been enacted about half a century ago, in 1872. Within this area waterfowl shooting is regulated to a certain extent by special State laws, providing rest days, prohibiting night shooting, limiting the use of 
sink boxes and decoys and requiring licenses for the use of such paraphernalia, and providing a special warden system. The proceeds from licenses are applied to the payment of salaries of the wardens, who are appointed directly by the governor and are more or less independent of the State warden.

The Pennsylvania system of preserves is unique; it consists of a number of small irregular areas on State lands, each not more than 9 miles in circumference and marked by a single wire fastened to the trees. No hunting is allowed within these areas and no one is permitted to enter the inclosures during the open season. Deer when pursued outside thus find a real refuge within the inclosure. At least 30 or more such refuges have thus far been established.

After an experience of several years the Pennsylvania refuges have proved very effective in maintaining and increasing the supply of deer in their vicinity. The State has 1,029,023 acres of State forests, which in effect furnish public camping and hunting grounds, much as the Adirondack Forest does in New York, with the difference that Pennsylvania is actively stocking and increasing the supply of deer through the medium of these small refuges, whereas New York relies entirely on regulating the hunting and on the natural increase of the stock, without resorting either to restocking or to maintaining natural refuges.

The most recent project of this kind is the Pass a Loutre public shooting grounds located in southern Louisiana at the mouth of the Mississippi River. This great waterfowl resort, comprising some 60,000 acres between Pass a Loutre and South Pass, is within easy reach of New Orleans and was opened to the public on November 1, 1921. It provides a place where 100 sportsmen may hunt at one time and that may be enjoyed by the public at a minimum of expense. Here the hunter who can not afford to belong to an exclusive duckhunting club may enjoy the same advantages of wild-fowl shooting as a club member merely at the cost of his hunting license, a permit from the conservation commission, and his actual expenses while shooting on the reservation. The principal kinds of ducks to be found during the season are mallards, pintails, spoonbills, gray ducks, canvas-backs, redheads, teal, and lesser scaups. In creating this reservation Louisiana has set an example, which will doubtless be followed by other States, in utilizing and developing some of her marshlands for the benefit of the public rather than permitting them to pass into private ownership or allowing the shooting rights to be monopolized by a few private clubs.

Several years ago Michigan enacted a measure providing hunting grounds on Saginaw Bay, but nothing practical seems to have been accomplished by this legislation. A former game commissioner of Utah advocated a provision for public hunting grounds on lands in 
Salt Lake, Daris, and Box Elder Counties, but this project has not thus far been carried out.

GAME REFUGES.

The object of establishing game refuges in places where certain birds and animals may receive protection throughout the year, is to permit native species to increase under natural conditions and thereby to restock surrounding territory. In recent years many experiments have been made in establishing State game refuges, both on public and on private lands. The State refuge of to-day is a comparatively modern institution. One of the oldest and best known reservations is the Teton State Game Refuge in Wyoming, established in 1905. Refuges differ widely in character, in area, and in the methods by which they are administered. Some are on Federal lands, some on State lands, and some on private lands, the private lands being held under contract for the purpose of game protection and being posted by the State. In size they range from a few acres to reservations contaiming several hundred square miles. One of the largest refuges in the United States is the Superior State Game Refuge in Minnesota, comprising in part Federal lands in the Superior National Forest and in part adjacent State and private lands. The States which have the largest aggregate areas devoted to game refuges are California, Minnesota, and Wyoming; those which have the greatest number of individual refuges are probably Michigan and Pennsylrania. Michigan has 50 or more and Pennsylvania has 32 of a peculiar type already described. ${ }^{13}$ The development of the refuge policy in Pennsylvania is interesting. In 1905 the State game commission received authority with the consent of the commissioner of forestry to establish game preserves on State forest lands; in 1907 the area of a reserve was limited to a tract 9 miles in circumference, and in 1911 the size was increased, provided the greatest diameter did not exceed 10 miles and the area was not greater than that of half the forest reservation on which located.

In most cases insufficient time has elapsed to determine the most successful type of preserve or to learn the ultimate success of some of the projects which have been suggested, but in Pennsylvania, Wyoming, and Indiana data are now available showing actual experience with widely different types of preserves over a period of several years.

Wyoming was one of the pioneer States in the establishment of State game refuges and now (1921) has 13, the combined areas of which are perhaps not greater than the total area of State reserves in California or Minnesota, yet individually each is of considerable

${ }^{13}$ For a description of the Pennsylvania refuges, see Phillips, John M., Pennsylvania game preserves: In the Open, vol. 3, pp. 41-44, November, 1912. 
size. ${ }^{14}$ These refuges are all established on public lands, most of them within the boundaries of national forests. The Teton Reservation, lying immediately south of the Yellowstone National Park, was the first and originally the largest. It was created in 1905, and embraced practically all the area immediately adjoining the south boundary of the park between the State line on the west, Buffalo Fork on the south, and the West Fork of the Yellowstone River on the east. In 1913 the boundaries were modified so as to eliminate the western part of the reservation between the Idaho line and the summit of the Teton Range. This elimination was due to the fact that most of the game on the west slope of the Tetons had been destroyed and the expense and difficulty of patrolling this remote region was not commensurate with the adrantages gained. At the same time an addition was made in the southeast by extending the eastern part of the refuge up the Du Noir Creek. In 1917 another modification was made by eliminating the northeast corner of the refuge, including all the land north of Soda Creek and east of a straight line drawn from the junction of Soda Creek and the North Fork of the Buffalo north to the Continental Divide. The object of this change was to afford a larger hunting area for sportsmen from northern and central Wyoming by giving them hunting grounds between the Yellowstone River and the Continental Divide.

Thus in a period of 12 years the boundaries of the Teton Game Preserve have been changed three times and its original area, comprising about 576,000 acres, has been materially curtailed. The western section has been eliminated and the eastern boundaries have been first extended, then curtailed. While they still include the lower lands in the southeastern part of the refuge, this section lies in the form of a wedge extending at right angles to the general line of migration of the elk and is of little value, inasmuch as the elk can easily be driven out of it to open lands.

Two elements are essential for the success of any game refuge: First, permanency; and, second, sufficient area in a compact body. For the protection of big game, long narrow strips of territory are comparatively worthless and constantly shifting boundaries furnish little actual protection.

The Indiana game refuges, all established on private lands under contract with the owners, represent the other extreme from those of Wyoming. The idea was conceived and put into execution by the late Z. T. Sweeney, commissioner of fisheries and game from 1899 to 1911. Under his plan contracts were entered into between the State game commissioner and owners of contiguous farms providing

${ }^{14}$ Under recent order's of the game and fish commission some hunting is permitted on the Big Horn, Popo Agie, and Split Rock Special Game Preserves. 
that if owners would forego the privilege of hunting on their own lands the State rould post such lands as State game preserves and stock them with game birds. No preserves were established unless agreements could be made with the owners for at least 400 acres of land forming a solid body nor for areas larger than 3.000 acres. In 1909 the State legislature passed an act affording a certain measure of protection to these preserres. This law provided:

That it shall be unlawful for any person in the State of Indiana for and during the term of six (6) years from and after the passage of this act to injure, take. kill, expose, or offer for sale, or hare in possession, except for breeding purposes, any prairie chicken, ans ring-neck IIongolian pheasant * * or Hungarian partridge; or to hunt upon any game preserre organized or stocked with any of the abore mentioned birds by the commiss:oner of fisheries and game: Provided, That any landowner living within the territory of the preserre mas be permitted to hunt squirrels and rabbits on his own land only. (Laws of 1909, chap. 103, approved Mar. 6, 1909.)

In 1911 the commissioner referred in the following terms to the experiment of introducing Hungarian partridges. which began in 1909. and for which the system of preserves had been partly established:

There are now in the state 240 of these preserves, and they inclose in all something like $1,500,000$ acres of protected breeding grounds for game birds. In most of the counties there are as many of them as there ought to be.

By the first of the rear 1910 Mr. Sweeney had established about 170 of thest preserves, and on them he placed some 3,000 pairs of Hungarian partridges Recent reports from them, with three or four exceptions, hare been that the birds hare done well during the past season. and that a great many broods have been hatched and reared on them. (Bien. Rept. for 1909-10, pp. 99-100.)

In March, 1915. this la $\pi$ expired br limitation, and in reviering its history the commissioner of fisheries and game referred in his report in December, 1916, to the fact that there was at that time no game preserve law in effect. He further stated:

The provisions of this law were so indefinite and inadequate that the preserves established under its provisions were not the success they should have been. In many cases, it is claimed, the owners of the lands which were included in the preserve used the "State game preserve" signs to keep others out, and made it a prirate hunting ground.

A few years ago a large sum of mones, approximately $\$ 70.000$, was expended in the purchase of Hungarian partridges and English ring-neck pheasants. which were distributed throughout the State, most of them being planted on game preserres which were then in existence. To-day rery few of these birds are left. They not only failed to increase in number, but those that have survired constitute only a small per cent of the original stock planted. That the experiment was unsuccessful is beyond question. Tery little satisfactory information as to why this was so can be obtained. (Bien. Rept., 1914-15. pp. 54-55.) 


\section{RESTOCKING DEPLETED AREAS.}

No field of conservation is more important than the restoration of game in regions where it has been reduced to the vanishing point or completely exterminated. Plans for bringing back the game lisually involve legislation, introduction, or propagation.

Legislation is the most popular method, and while indispensable in combination with others, it is the most disappointing when relied upon exclusively. Legislation failed to save either the buffalo or the passenger pigeon and can not by itself save any game after a species has been reduced beyond a certain point. Nevertheless, when enacted in time it not only may save the game but may result in its increase beyond normal conditions. Striking illustrations of the efficiency of legislative protection are afforded by the history of deer in Pennsylvania and of mountain sheep in Colorado. In recent year's under a consistent and conservative policy of conservation in Pennsylvania deer have increased to such an extent that about 4,000 are obtained during the open season. Colorado has maintained a close season on mountain sheep ever since 1885, with the result that these valuable game animals have not only increased but the sentiment in regard to their protection has changed to such a degree in certain sections, notably near Estes Park, that every effort is made by the public to prevent them from being destroyed, and during serere winters the animals are systematically fed.

For many years efforts have been made to increase the stock of certain kinds of game by introducing species from other sections of this country or from abroad. Experiments have been made with many species, but the most important work has been done with quail. Hungarian partrıdges, pheasants, deer, and elk.

RESTOCKING WITH G.ME BIRDS.

Quail.-The earliest efforts to increase the stock of quail in America were directed toward the introduction of the Messina, or migratory. quail (Coturnix coturnix) of Europe. These experiments began in the seventies and were continued for several years. Thousands of birds were imported and liberated at rarious points in the Eastern States, especially in the New England and Middle Atlantic States. Much money and considerable effort were spent in the attempt to acclimatize the birds and establish them in suitable places, but without permanent result. The birds were migratory and, although they seemed to thrive for a few months, when liberated they eventually died or disappeared and the experiment was a failure. ${ }^{15}$ About 1895, when an Asiatic species of quail of the same genus (Coturnix

15 Notes on these experiments in 1879 , when nearly 3,000 quail were distributed, will be found in Forest and Stream, vol. 12. pp. 371, 412, 1879. 
jeponica) was being imported from (hina for the San Francisco market, some sporadic efforts were made to acclimatize the birds in California. These quail were imported alive in large numbers and it was easy to obtain stock at certain seasons, but like the Messina gluail they were migratory and the experiment of introducing them as a game bird proved a failure.

The plan of introducing Old World quail having proved unsuccessful. efforts were made to obtain native stock from States where quail were still abundant. In the late nineties large numbers of quail were shipped east. north, and west from Kansas and Indian Territory. The demand for these birds grew to such an extent that it was impossible to supply the market, and the States where the birds were captured, fearing serious depletion of the stock, prohibited export. In 1907. the last year in which any considerable number of quail were captured for shipment in the United States, a disease, commonly known as quail disease (Colibacillosis tetraonidarum), was discovered in a number of consignments sent to points in the North and East from Alabama and the Southwest. Three or four years later, because of the scarcity of native birds, efforts were made to obtain stock in northeastern Mexico, but each season, notwithstanding the precautions and quarantine regulations, quail clisease appeared in some of the shipments. In the winter of 1916-17 the importations of Mexicun quail totaled 32.814; about half of these birds were obtained by the game commissions of two northern States and more than 50 per cent of them died soon after they were distributed. In the winter of 1919-20, 864 birds imported died in quarantine or were returned to Mexico because they were infected with quail disease. Many others lied after reaching their destinations. The total number entered that season was 22.209.

Hungarian partridges.-The difficulty in securing an adequate supply of native quail encouraged importers to endeavor to meet the rleficiency by bringing in the European gray partridge (Perdix perdix) under the name of Hungarian partridge. The adrantages of introducing the bird were widely advertised and a thriving trade was developed by a few importers. Game commissioners and game protective associations were induced to liberate the birds in as large numbers as the funds at their disposal would permit. In some instances favorable reports of the success of these experiments were made for the first year or two after the birds were liberated, but in most States the introductions were unsuccessful except in eastern Washington. The birds usually sold for $\$$ or or $\$ 6$ per pair, and from 1906 to 1915 many thousands were imported. High-water mark was reached in 1914, when 36,760 were brought in, while the total number imported during the decade was 174,294. Thousands of dollars were expended, but comparatively few partridges can now be found in 
sections where many birds were liberated a few years ago. For example, the State of New Jersey, which purchased partridges liberally for several years, ceased the distribution in 1912. Four years later investigation showed a total of 45 coveys with about 490 birds in the State, while in 1918 the number had decreased to 23 coreys with a total of 115 birds.

Pheasants.-For 40 years pheasants have been imported and liberated in varying numbers in many parts of the country. The success of the introduction of the so-called ring-necked pheasant, first imported in Oregon in 1887 and 1888, and the success with English and ring-necked pheasants in the Genesee Valley, N. Y., and in some sections of Massachusetts, encouraged other States to undertake similar experiments. Pheasants and pheasant eggs were imported in considerable numbers from Europe, chiefly from-England, and in recent years from several points in Ontario, but with the beginning of the war these shipments rapidly diminished and comparatively few birds have been brought in since. Notwithstanding the suspension of importations, there are more pheasants in the United States now than ever before, and nearly all are the product of stock raised in the United States. In many places the bird has become well established and in a few States sufficiently abundant to permit an open season for a limited period in the autumn, notably in Massachusetts, Connecticut, New York, New Jersey, Pennsylvania, and Washington, and formerly in Oregon.

The following table shows the importations of the principal upland game birds from 1906 to 1915, inclusive:

Importation of principal upland game birds, 1906 to 1915.

[Fiscal years ending June 30.]

\begin{tabular}{|c|c|c|c|c|c|c|c|}
\hline Ytar. & Quail.1 & $\begin{array}{l}\text { Hungarian } \\
\text { partridges. }\end{array}$ & Pheasants. & Year. & Quail. & $\begin{array}{l}\text { Hungarian } \\
\text { partriagges. }\end{array}$ & Pheasants. \\
\hline \multirow[t]{2}{*}{$\begin{array}{l}1906 \ldots \ldots \ldots \\
1907 \ldots \ldots \ldots \\
1908 \ldots \ldots \\
1909 \ldots \ldots \\
1910 \ldots \ldots \\
1911 \ldots \ldots\end{array}$} & \multirow[t]{2}{*}{$\begin{array}{r}2,896 \\
1,428 \\
-\quad 649 \\
868 \\
1,379 \\
3,110\end{array}$} & \multirow{2}{*}{$\begin{array}{r}864 \\
3,075 \\
7,781 \\
29,832 \\
18,932 \\
36,507\end{array}$} & \multirow{2}{*}{$\begin{array}{r}1,151 \\
4,970 \\
4,420 \\
22,268 \\
9,496 \\
13,398\end{array}$} & \multirow{2}{*}{$\begin{array}{r}1912 \ldots \ldots \\
1913 \ldots \ldots \\
1914 \ldots \ldots \\
\text { Total. }\end{array}$} & \begin{tabular}{c}
7,570 \\
2,936 \\
\hdashline 3,341
\end{tabular} & $\begin{array}{r}23,181 \\
10,283 \\
36,760 \\
7,080\end{array}$ & $\begin{array}{r}15,412 \\
9,417 \\
4,148 \\
15,841\end{array}$ \\
\hline & & & & & 24,177 & 174,295 & 80,521 \\
\hline
\end{tabular}

1 Importation of quail from Mexico began in 1910 and the figures in the above table refer mainly to Mexican birds. The number imported in 1916 was 8,000; in 1917, 32,814; in 1918, 5,205; in 1919, 4,358; in 1920, 23,473; and in 1921, 22,209. In all, about 115,000 Mexican quail have been imported in 11 years.

21,100 aviary pheasants.

RESTOCKING WITH DEER.

Deer increase so rapidly when given adequate protection that there has been comparatively little necessity for general restocking except in a few places. Two of the experiments thus far made, in New Jersey and Vermont, have met with such success as to attract wirlespread attention. 
In 1899 a close season on deer for 10 years was provided in New Jersey and a number of deer obtained through the game commission were liberated in suitable sections of the State. When the season opened in 1909 hunting was limited to bucks and restricted to one day, Wednesday, in each week in Norember; later the season was opened for four or five days. In 1915 the season was opened on both bucks and does, and 293 of those killed were does. The following is a record of 3,626 deer killed in 12 years :

Deer killed in New Jersey, 1999 to 1920.

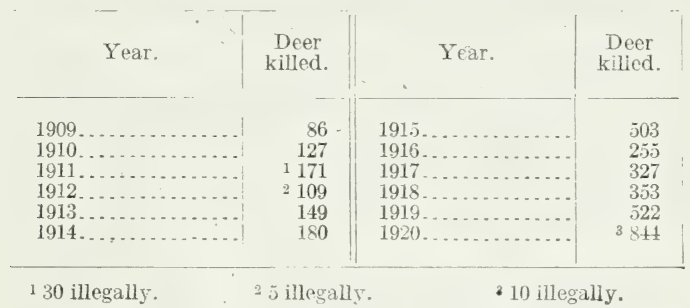

In comparison with the results elsewhere the number of deer annually killed in New Jersey is small, but as the area there available for deer is limited and the season short, the discrepancy in the results is not so great as would appear at first sight. In Vermont the total number of deer killed during the first 10 open seasons was 3,489 , and the daily average was about 58 ; while in New Jersey the total number was 2,260 and the daily arerage was 56 , but in New Jersey the large number killed in 1915, and the correspondingly high daily average, were due to the fact that nearly 60 per cent of the deer killed were does.

The experiment of reintroducing deer into Vermont merits special attention, because it has been a marked success and because the records are sufficiently complete to make it possible to trace each step in the work. Sixty years ago deer were practically extinct in the greater part of Vermont, except in Essex County in the northeastern corner of the State. At that time the Rutland County sportsmen undertook the task of restoring the deer. Funds were collected, 17 deer were obtained from various sources, chiefly from Dannemora, N. Y., and liberated in the county, and in 1865 a close season of 10 years was established by the legislature. Since 1876 the close season has been extended from time to time so that the deer enjoyed almost uninterrupted protection for 32 years, from 1865 to 1897, except during the open seasons of 1875 and 1876 . In addition, a standing reward of $\$ 50$ was offered for evidence which would lead to the conviction of anyone riolating the law. Under this protection the deer increased rapidly and spread throughout the State and also into adjoining States. 
Nearly a quarter of a century has now elapsed since the seasom was first opened, and the results of the experiment can be appraiser more accurately than those of almost any similar work in the country. Tot only has a record been kept of the number of cleer killed during the short open sasons each year but there is a record of the deer reported killed by dogs. by accident, and illegally. In round numbers about 41,000 deer have thus far been killed during the hunting seasons from 1897 to 1920 , inclusive, and about $3,200 \mathrm{by}$ accident, out of season, etc.: in other works, all together, an average of about 1,845 deer have been shot during each of the 24 vears. During the first decade only about 10 per cent of the total number were obtained, but in recent years the annual deer crop has increased rapidly. The number killed each year during the open season or otherwise is shown in the following table, the figures for deer killed illegally, by accident. etc.. being for the biennial term ending June 30 of the year following date in which the entry appears:

Record of deer killed in Vermont, 1897 to 1920.

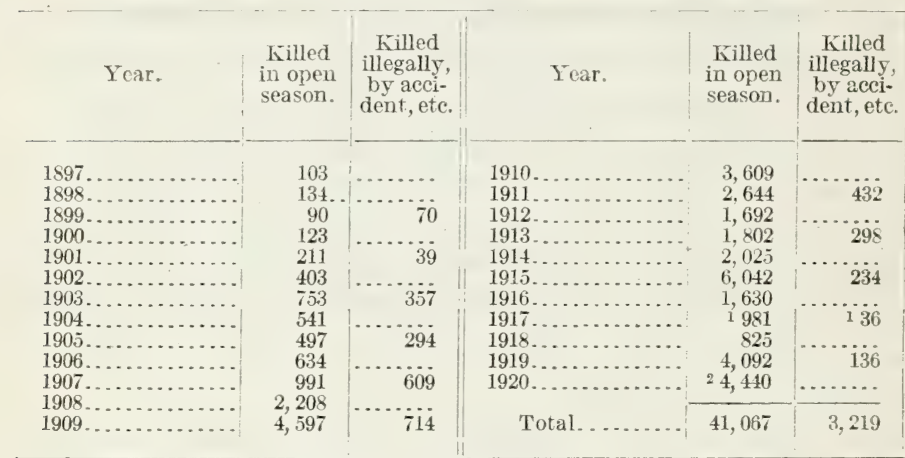

${ }^{1}$ Sportsmen's Reriew, vol. 52, p. 543, Dec. 15, 1917.

: Field and Stream, vol. 26, p. 295, July, 1921.

Three factors-limits, sex, and seasons-enter into the consideration of these figures. The first year the season was open each hunter was allowed to kill two deer, but since 1898 the limit has been reduced to one. The killing has been restricted to bucks except in 1909,1910 . 1915,1919 , and 1920. The abnormally large numbers of deer killed in these years were evidently largely made up of does. In 1910, when an exact record was kept, the numbers were 1,749 does of an average weight of 146 pounds and 1.860 bucks of an arerage weight of $17 t$ pounds; and in 1919, 2,138 does and 1,954 bucks. In 1918 the arerage weight of both bucks and does was 175 pounds and in 1919 the arerage was 140 pounds. The suspension of the doe law in 1915 evidently proved disastrous to the species, as shown by the greatly reduced number obtained the following year, a number less than that obtainer in any previous season for eight years. 
The hunting season was originally open during the whole month of October, but after the first year was shortened to the last 10 days in the month. From 1905 to 1910 , inclusive, the season was further shortened to the last 6 days in October, except in 1908, when it was postponed until the second week in Norember on account of the drought and consequent danger from forest fires. In 1911 the season was lengthened and made later to include the 10 days from November 15 to 25. In 1913 it was again lengthened, this time to the last 3 weeks in Norember; in 1915 the opening date ras again postponed to November 15 ; in 1917 the season was 9 days, Norember 10-20; and finally in 1919 it was made the first full meek in December. In all the changes an increasing effort is apparent on the part of those in favor of hunting to kill more and more deer, either by lengthening the season or shifting it to the most farorable dates, and occasionally by taking adrantage of local prejudice due to damage done by deer. to gain temporarily the privilege of killing does. In 1919 the legislature authorized the fish and game commissioner on application of the owner to establish orchard zones around commercial orchards of 10 acres or more where deer could be killed at any time. During the first year nine such zones were established and the number of deer killed was 49.

Three other examples deserve mention in this connection, although the restocking has been done by natural rather than by artificial means. In Pennsylrania, through a judicious system of protection, deer have increased rapidly, and in addition to the native stock considerable numbers have been liberated for restocking preserves and counties where deer had become scarce. Some of the animals were obtained from local preserves and others were imported from northern Michigan. In Massachusetts deer have repopulated the State to such an extent that an open season of six days has been provided for several years. When the season was first opened in 1910, 1,281 deer were killed; during the same year the number killed on account of damage to crops or for other causes was 598, making a total of 1.879 killed during the year. In Nora Scotia deer have increased remarkably in recent years. They were not originally native in the Province, but have spread eastward from New Brunswick. Apparently the first deer was killed in December, 1886. Soon after a continuous close season was placed on the species, and when the season was first opened in 1916, 154 bucks were killed.

RESTOCKING WITH ELK.

The most successful experiments in restocking areas with big game have been the transfers of elk from the Yellowstone National Park and Jackson Hole, Wyo.. to various points in the United States. 
These transfers began in $1910,{ }^{16}$ and for the first two years were merely on an experimental basis. Beginning in 1912, several hundred elk were shipped each year under Federal and State auspices, and the total number distributed during the last 12 years has been about 4,000. Methods of capture and transportation have been greatly improved and costs of transportation reduced, and the losses have been comparatively small, probably not more than 10 per cent. In some cases elk have been transferred from the Yellowstone Park to Eastern States without any loss en route. The greater number of the animals were obtained from the northern herd in the Yellowstone Park and shipped from Gardiner, Mont. A smaller number were captured in Jackson Hole, transported over the Teton Pass on sleds to the railroad at Victor, Idaho, and thence

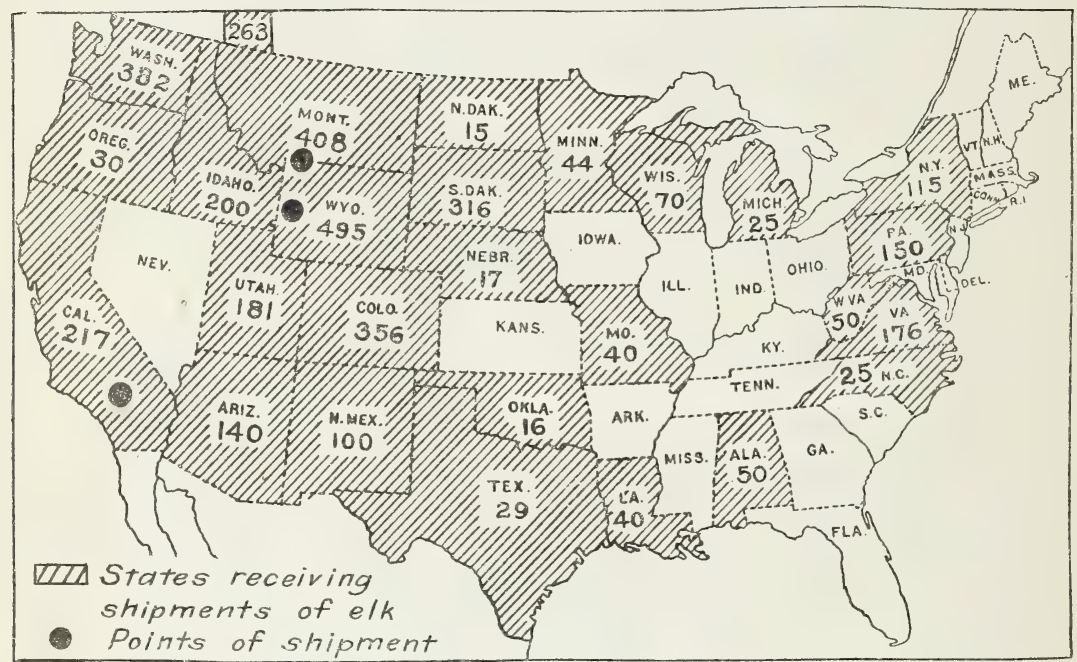

Fig. 4,-Elk shipments for restocking purposes. Spots indicate points of shipment; shaded areas, th States receiving elk; and figures, the total number of elk received by the States and Canada.

shipped to their destination. Shipments thus far made to 25 States and Canada (see map, fig. 4) may be roughly divided into five groups: $(\alpha)$ From the Yellowstone National Park to other States: (b) from the park or near-by points in Montana to other sections in the State; (c) from Jackson Hole, Wyo., to other points in the State; $(d)$ from Jackson Hole, Wyo., to other States; and (e) from Buttonwillow, Calif., to other points in the State.

As a rule these elk have done well in their new locations; already a number of new herds have been well established, and in the course of a few years they should increase to considerable proportions. As might have been expected in transferring so many ellk, some of the locations selected have been ill-advised and complaints have been 
made of the damage done to farms in the neighborhood, calling for the transfer of these herds to new locations. The number of such mistakes, however, has been small. The following tables give a summary of all elk transferred and the destination of the elk transferred each year.

Summary of all elk transfers, 1905 to 1920.

[Fiscal years ending June 30.]

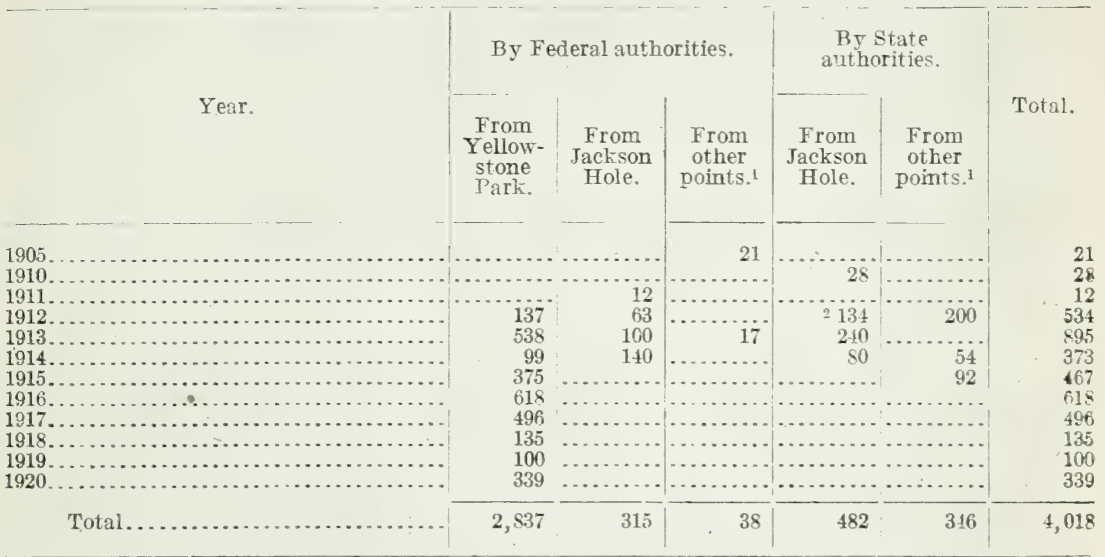

1 Miscellaneous shipments originated as follows: Federal-1905, California; 1913, Nebraska; State-1912, Montana; 1914-15, California.

2 In the Jackson Hole shipments of 1912, 12 head were sent to Minnesota and the others to Wyoming

I)estination of all elk transferred, 1905 to 1920.

[Fisca! years ending June 30.]

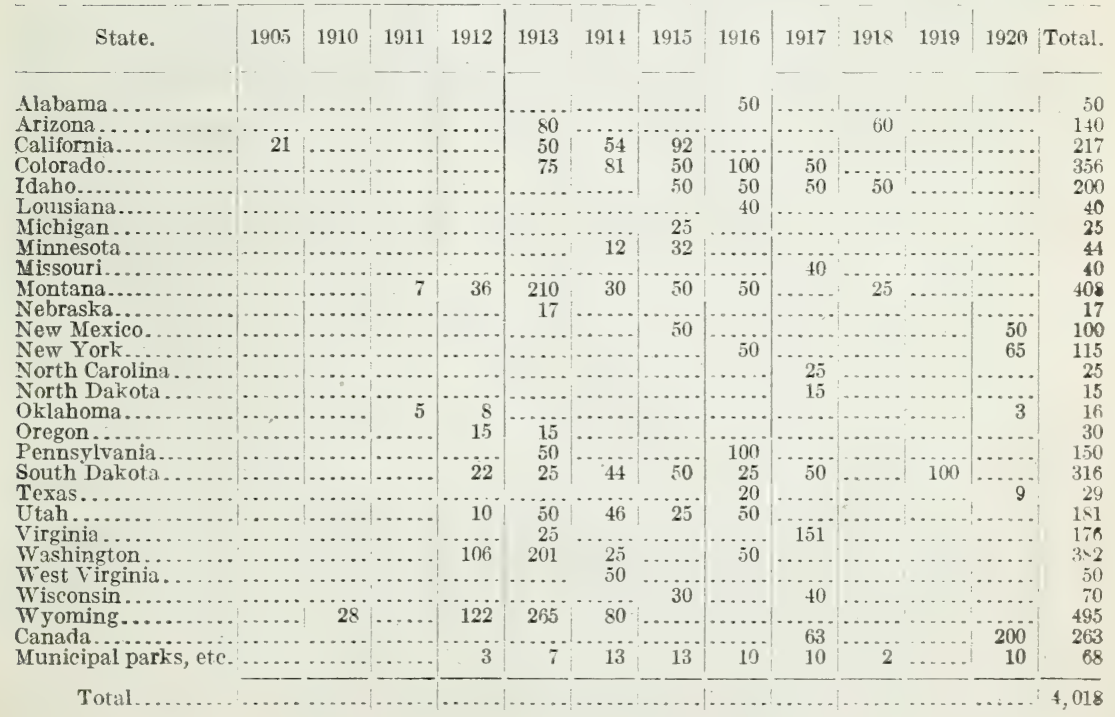




\section{GAME BREEDING.}

STATE GAME FARMS.

In recent years a number of efforts have been made in several States to increase the amount of game by propagation and by the distribution of certain kinds of game birds. Propagating plants, commonly known as game farms, have been established under State auspices for the purpose of producing as many birds as possible. Some of these farms have been operated in connection with fish hatcheries, others have been established as independent organizations.

The kinds of birds which can be propagated in any considerable numbers are necessarily limited. Pheasants, chiefly ring-necked and English pheasants, are the ones most commonly raised, and a few of the other species, such as silver, golden, Lady Amherst, and Reeres, are produced on a small scale, mostly for exhibition. Mallards and black ducks, wood ducks, and wild turkeys are also raised in considerable numbers.

Among the more important game farms have been those estab)lished in Massachusetts, Connecticut, New York, New Jersey, Delaware, Ohio, Illinois, Minnesota, Missouri, Iowa, Oregon, and California. In several cases the farms have been abandoned after a trial of a few years on account of the expense involved or because the results were unsatisfactory. Ohio abandoned the raising of pheasants about 1902, but has recently again taken up the propagation of game birds. The most extensive game farm thus far established was probably that of Illinois, near Auburn, 16 miles south of Springfield. established in the spring of 1905 , and abandoned about 1915.

The California game farm raised pheasants and also experimented to some extent with wild turkeys imported from Mexico. The Illinois farm raised numbers of English call-ducks for distribution among sportsmen interested in duck shooting, chiefly along the Illinois River. The Massachusetts commission has experimented in raising quail and ruffed grouse in captivity, but this work has not vet reached large proportions and the raising of ruffed grouse is still in an experimental stage. Much good work has been done at the New Jersey State game farm near Toms River, where pheasants, quail, and rabbits have been propagated. The most extensive State farms now in operation are those in New York, of which there are three-at Brownsville. Jefferson County; Sherburne, Chenango County: and Middle Island in Suffolk County. In 1919 these farms (listributed 9,206 half-grown birds and 55,400 eggs for propagation.

The whole question underlying the successful operation of game farms is whether birds can be produced more cheaply under State auspices than they can be bought from private breeders. Arrocates of game farms assert that game can be produced as economically on a 
State game farm as it can be purchased in the open market, and furthermore that it is not always possible for the State to obtain the necessary stock of birds if dependence is placed upon open-market purchases. The factors which militate against the attainment of this ideal are frequent changes in administration, the question of labor, and the constant pressure for immediate returns. Changes in administration of game departments prevent consistent development of definite policies and encourage the adoption of temporary methods which promise showy results; the limitation on hours of labor, and the necessity of hiring foremen and superintendents who have no permanent pecuniary interest in the success of the farm greatly increases the cost of maintenance; while the demand for immediate. results causes efforts to be made beyond the capacity of the plant, and tends toward the distribution of immature stock. The distribution of eggs or of birds only a few weeks old makes a showing in numbers, but the percentage of loss is very high, so that the ultimate benefit to the public is much less than if a smaller number of birds had been raised to maturity before being liberated. This factor also renders difficult a fair comparison of results on State and private farms. Owing to the high initial cost of establishing a farm and the short time in which most game farms have been in operation. data are not ret available to determine definitely whether it is economical for the State to raise its own birds.

PRIVATE GAME FARMS.

The breeding of game on private farms, particularly the breeding of game birds, has made rapid progress in recent years and gives promise not only of becoming an important factor in increasing the supply of game, but of establishing an important industry. Already the game breeders number several hundred, a journal devoted to their interests has been established, a game breeders' convention is held in New York each year. and a course in practical game breeding has been provided at Cornell University.

In addition to rork done by the State game farms already mentioned. many persons are now propagating pheasants and waterfowl. and with the spread of interest in this work the hope increases of raising some kinds of game in sufficient numbers to make it abundant in certain localities. At least one private pheasantry has raised 10,000 birds a vear, and several breeders have raised a thousand or more wild ducks. When this work has increased tenfold an enormous number of birds will be available for liberation each year. Since the beginning of the war the importation of pheasants and other game birds for propagation has fallen off rapidly and nearly all the stock on the market in the Cnited States is raised in this country. 
Most persons interested in this work are engaged in raising phearsants, some in rearing waterfowl, and a few in raising wild turkeys. Attempts to raise quail. ruffed grouse, and prairie chickens in captivity hare met with some success, but have not as yet progressed beyond the experimental stage. What is now needed is the development of simple methods of rearing these birds so that those who liare had experience in raising poultry may engage in raising quail. grouse, wild turkeys, wood ducks, wild geese, and other native species in sufficient numbers to render the renture successful from a commercial standpoint. The demand for such game is greatly in excess of the supply, and the market is capable of being developed enormously provided the game can be produced cheaply enough to be sold at reasonable prices. ${ }^{17}$

\section{COST OF MAINTAINING GAME.}

COST OF WARDEN SERVICE.

The principal expense connected with the protection of game is the maintenance of a patiol adequate to prevent violations of the laws. The growth of the warden service has dereloped steadily in the last few years, and in some States the derelopment has been rapicl. Until recently wardens were paid part of the fines, but this sritem. always unsatisfactory, has now been abandoned in most States. The next step was payment by the day when actually employed; this method is still followed by some States but fails to produce satisfactory results, as it is impossible to maintain an efficient force when men are uncertain of their pay and must rely on other emplorment to eke out their incomes. The third step, the employment of salaried wardens throughout the year, is the most satisfactory method thus far derised and makes it possible to develor) a permanent and efficient force.

Wardens' salaries are now paid mainly from receipts from hunting licenses, and in many States the income from this source is sufficient to make the warden serrice self-supporting without cost to the general tax payers. The total cost to the state for such service depends chiefly on the amount of the salary and the number of the wardens. The salaries formerly paid deputies or field men were at the rate of $\$ 50$ or $\$ 60$ per month, but sereral States now pay from $\$ 100$ to $\$ 125$ per month. the rate being graded according to the character of the work and the experience of the men. District or superrising wardens receive more. and in New York the chief game prortector receives a salary of $\$ 5,000$ per annum.

${ }^{17}$ The Department of Agriculture has issued two bulletins on the propagation of wild-duck foods, which may be had on application: McAtee, W. L.. Eleven important wild-iluck foods; Bull. 205, pp. 25, figs. 23, 1915. MeAtee. W. L.. Propagation of wild du k foods: Bull. 465, pp. 40, figs. 35, 1917. 
Now York, which has the most completely organized warden force of all the States. in 1919 had 125 game-protectors under a chief protector, a deputy chief protector, and sereral inspectors. The total cost of the service in the year ending June 30, 1919, was $\$ 323,265.19$. Of this amount, $\$ 180,166.21$ was expended for salaries of protectors; $\$ 9,976.50$ for wages; $\$ 88,909.40$ for trareling expenses; $\$ 3,434.19$ for

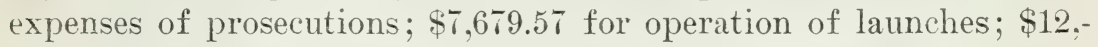
472.13 for printing; $\$ 10,596.40$ for equipment and supplies, including hunters' buttons; and $\$ 10,030.79$ for miscellaneous items. The law provided for the appointment of 131 game protectors in 1920 at $\$ 1,200$ to $\$ 1,500$ each; 12 inspectors at $\$ 1,800$ each; a deputy chief game protector at $\$ 3,000$; and a chief protector at $\$ 5,000$. The salary roll authorized for these officers amounted to from $\$ 186,000$ to $\$ 226,100$. With allowances for traveling expenses, operation of launches, and miscellaneous items, the total expense authorized for warden service was fully $\$ 350,000$. On the other hand, receipts from hunting and other licenses and miscellaneous income from fish and game for the fiscal year 1919 amounted to $\$ 382,499$.

\section{COST OF GAME REFUGES.}

NATIONAL GAME REFUGES.

In any consideration of the matter of the cost of game refuges, whether national, State, municipal, or private, it is important to distinguish between the original cost of establishment and the expense of maintenance. In the case of national refuges comparatively little has been expended in the purchase of lands, as most of the areas originally belonged to the Federal Gorernment, but there have been some expenses for inclosing or for stocking them. In four cases it was necessary for the Government to purchase the areas on which the reservations are now located. The land for the National Bison Range, on the former Flathead Indian Reservation, Mont., was purchased from the Indians in 1908 at a cost of $\$ 30,000$, and the expense of inclosing it and making it ready for game brought the total cost to approximately $\$ 50,000$. In establishing the winter Elk Refuge, in Jackson Hole, Wyo., it was necessary to purchase some tracts which were already under cultivation in order to obtain lands on which hay could be raised for the animals, and for this purpose Congress made appropriations aggregating $\$ 50,000$. In the case of the game preserve in the Wind Cave National Park, S. Dak., to secure an adequate water supply it was necessary to acquire a small private holding within the park and some additional land adjoining the northern boundary, and about 456 acres, purchased for this purpose at a cost of $\$ 9,880$, were thus added to the park. Recently, the Pisgali Game Preserve, in the Appalachian Forest in North Carolina, was 
located on private lands purchased under the Weeks Act for watershed protection.

Congress has made sereral special appropriations for inclosures or other improvements in establishing refuges to provide for game acquired by donation or otherwise. In 1902, an appropriation of $\$ 15,000$ was made for the Yellowstone National Park for purchasing a herd of buffalo (20 head), constructing a suitable inclosure, and meeting incidental expenses of installation. In $1906, \$ 15,000$ was appropriated for constructing a fence on the Wichita Game Preserve, Okla., and in 1913, $\$ 2,000$ for erecting suitable headquarters. In 1910 , an appropriation of $\$ 26,000$ was made for the improvement of the Wind Cave National Park, by the establishment of a game preserve, including the acquisition of the lands above mentioned. For the Sullys Hill Park, N. Dak., there have been five appropriations of $\$ 5,000$ each for improrements, including fencing, constructing headquarters, roads, etc.

The cost of maintenance of the various reservations is rery moderate. The annual appropriation for the care of the buffalo in the Yellowstone Park until recently has been $\$ 3,000$ (later $\$ 5,000$ ), and a small appropriation is made for the Wichita Game Preserve. Most of the other mammal and bird refuges under the charge of the Department of Agriculture, including 5 big-game refuges and 65 bird reservations, have been maintained for several years under an annual appropriation of approximately $\$ 35,000$, increased to $\$ 39,735$ for 1921. During the spring of 1920 emergency appropriations amounting to about $\$ 75,000$ were made for feeding elk in the Yellowstone National Park and in Jackson Hole, Wyo.

\section{STATE GAME REFUGES.}

In marked contrast with provisions made in connection with national refuges, States seldom make any expenditures for lands on which to establish game preserves, although liberal appropriations are made for game farms. In providing for improvements where necessary, or for costs of maintenance, much more liberal appropriations are made as a rule than in the case of national reserves. State refuges are usually located either on lands acquired by the State or on lands which have reverted to it through nonpayment of taxes, or occasionally, as in South Dakota, through exchange with the Federal Government for school lands within Government reservations in other parts of the State. In New York, Pennsylvania, and Wisconsin the lands have been purchased by the State primarily for forestry purposes, and not chiefly for the establishment of game reserves. In Louisiana an area of about 15,000 acres on Vermilion Bay has been donated to the State for a game reservation. More recently the great Marsh Island and Rockefeller Preserves have also been donated to 
the State, and a large area in another parish has been placed at the disposal of the conservation commission for experiments in game protection, including the introduction of elk.

The expense of inclosing a preserve is shown by reports ${ }^{18}$ regarding the Custer County refuge, South Dakota, comprising 61,440 acres and inclosed by a fence of woven and barbed wire 40 miles long and 8 feet high. The construction of this fence was begun in July, 1913 , and completed in November, 1914, and cost $\$ 12,261.05$. In the autumn of 1914, 36 head of buffalo were purchased from the Philip herd, Pierre, S. Dak., including 6 bulls, 18 cows, and 12 calves. Early in 1915, 50 elk were obtained from the Yellowstone Park; in 1916, 25: and in 1917, 50 more, making a total of 125 thus obtained. In June, 1921, the total number of buffalo was reported as about 70 and the number of elk about 500. A considerable number of deer are in the inclosure and the preserve has also been stocked with pheasants.

\section{COST OF GAME FARMS.}

The cost of maintenance of game farms may be illustrated by the costs of those operated by Illinois, Oregon, and New York.

The Illinois farm, now abandoned, formerly embraced about 534 acres near Auburn, a few miles south of Springfield, and was held under eight leases. The total expense for maintenance during the year ended June 30, 1912, was $\$ 67,142$. This total covered the following items: Expenses of the commissioner and purchase of food supplies, $\$ 20,665$; purchase of game birds, $\$ 18,267$; labor, $\$ 21,662$; leases, freight, and express charges, $\$ 6,548$. The purchase of game birds included $\$ 2,500$ for 1,000 ring-neck pheasant hens, at $\$ 2.50$ each; and $\$ 3,915$ for 783 pairs of Hungarian partridges, at $\$ 5$ per pair. About 15,000 birds were distributed during the year.

In 1914, the Oregon Fish and Game Commission expended \$12,891.16 on the State game farm. Of this sum $\$ 3,888.42$ were spent for salaries and labor, $\$ 4,385$ for supplies, $\$ 738.66$ for improvements, and $\$ 3,879.08$ for game. During the year, 5,686 pheasants, Hungarian partridges, and quail were distributed.

The cost of maintaining the three game farms operated by the Conservation Commission of New York during the year ended June 30, 1919, was $\$ 32,076.14$. Of this amount $\$ 13,365.18$ were expended for labor, and $\$ 18,710.96$ for miscellaneous expenses of maintenance and operation. The number of half-grown birds distributed was 9,206 and the number of eggs 55,400 .

\section{SUGGESTIONS FOR MAKING A SURVEY OF GAME RESOURCES.}

The information necessary for ascertaining the value of game resources can only be obtained by the adoption of comprehensive plans for collecting it on a broad and practical basis. In the fore-

${ }^{18}$ Rept. Dept. Game and Fish, S. Dak., 1914, p. $12 ; 1915$, p. 7 ; 1916, p. 19. 
going pages reference has been made to some of the experiments of this kind which have been tried in various States. Thus in the New England States provision has been made for appraising and paying for damage done to crops by deer and for ascertaining the number of deer killed in this connection. In the Rocky Mountain States of Montana, Colorado, and Wyoming, and in four of the Canadian Provinces, where guides are commonly employed, they are required to make reports of the amount of game killed by the persons employing them. In several States efforts have been made to obtain statistics of the number of deer killed during the hunting season, and in one or two instances estimates have been made of the total number of deer in a State.

A simple means of obtaining much of the desired information is already provided under the existing system of hunting licenses. State officers report with much detail the number of licenses issued, the amount of money collected for game protection, and the number of arrests made. More attention might be devoted to ascertaining the extent of the stock of game, which is the central point of interest of the whole game-protective machinery of the State. The following modifications of present methods of collecting data would furnish facts of the highest importance:

(1) Publishing in addition to the number of licenses issued an estimate of the number of persons hunting without license on their own lands or under exemptions allowed by law (an estimate which a State game commission could readily make) would furnish approximately the total number of persons hunting in the State.

(2) Requiring each big-game hunter to make a return of the results of his activities under his license, as is now done in several States and Canadian Provinces, would give accurate figures of the total number of deer and other big game annually killed.

(3) Requiring licensees to report the number of game birds actually killed would furnish returns similar to those needed in the case of big game, and while they would be much more difficult to obtain, yet with the necessary legislation and the cooperation of sportsmen's associations, local clubs, and the sportsmen themselves they could be collected, as shown by the results already accomplished.

(4) Requiring game farms to report the number of birds raised, disposed of for propagation, or sold for market would show the annual results of efforts to domesticate game.

(5) Estimating the total amount of each kind of game in the State would make it possible, by revising and comparing the estimates from year to year, to tell whether the stock is increasing or whether the total number killed exceeds the annual increase. 

